\title{
Federalism and the Generality Problem in Constitutional Interpretation
}

\section{Citation}

Manning, John F. 2009. "Federalism and the Generality Problem in Constitutional Interpretation." Harvard Law Review 122(8): 2003-2069.

\section{Permanent link}

http://nrs.harvard.edu/urn-3:HUL.InstRepos:41426673

\section{Terms of Use}

This article was downloaded from Harvard University's DASH repository, and is made available under the terms and conditions applicable to Other Posted Material, as set forth at http:// nrs.harvard.edu/urn-3:HUL.InstRepos:dash.current.terms-of-use\#LAA

\section{Share Your Story}

The Harvard community has made this article openly available.

Please share how this access benefits you. Submit a story.

\section{Accessibility}




\section{HARVARD LAW REVIEW}

(C) 2009 by The Harvard Law Review Association

\section{ARTICLE \\ FEDERALISM AND THE GENERALITY PROBLEM IN CONSTITUTIONAL INTERPRETATION}

John F. Manning

\section{TABLE OF CONTENTS}

I. LETTER VERSUS SPIRIT

A. The Holy Trinity Era 2011

B. The New Textualism....

II. THE NEW FEDERALISM .

2020

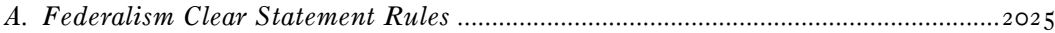

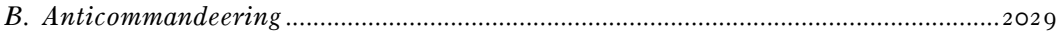

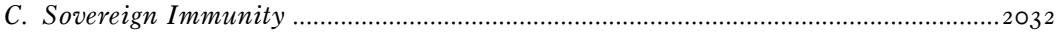

III. Constitutional COMPROMISE AND "OuR FEDERALISM" ....................................2037
A. Constitutional Compromise .2040

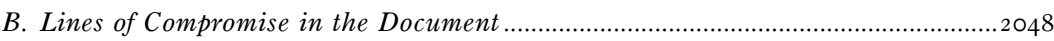

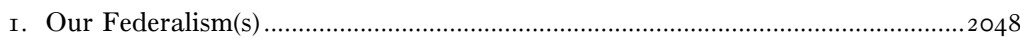

2. Vagueness, Purpose, and Compromise ………………………........................2052

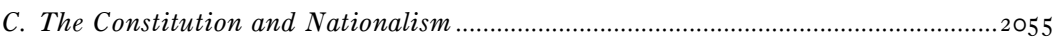

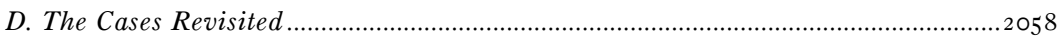

E. A (Brief) Look at Alternative Theories .................................................................. $206 \mathrm{I}$

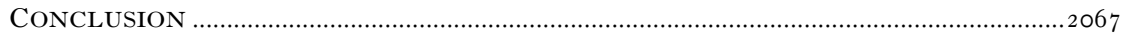




\title{
FEDERALISM AND THE GENERALITY PROBLEM IN CONSTITUTIONAL INTERPRETATION
}

\author{
John F. Manning*
}

\begin{abstract}
In recent years, the Supreme Court has embraced a freestanding federalism that is not tied to any particular clause of the Constitution. Rather, because multiple clauses assume the continued existence of states and set up a government of limited and enumerated powers, the Court has inferred that such provisions collectively convey a purpose to establish federalism and to preserve a significant degree of state sovereignty. The Court has treated that general background purpose as a warrant to derive specific but unenumerated limitations on federal power - in particular, a federalism clear statement rule, an anticommandeering principle, and broad state sovereign immunity from suit in state courts. This Article argues that the interpretive methodology underlying the new federalism cases cannot readily be squared with the process insights clearly articulated by the Court in its recent statutory interpretation cases, which endorse the related propositions that lawmaking entails compromise, that enacted texts select means as well as ends, and that abstracting from a law's specific means to its general aims dishonors the level of generality at which lawmakers choose to legislate. Despite evident differences between statutes and the Constitution, this Article maintains that where, as in the new federalism cases, the Court purports to attribute its holdings to decisions made by the founders pursuant to the processes prescribed by Articles $V$ or VII, its interpretive approach should proceed from the premise that constitutionmaking involves process considerations analogous to those that characterize legislation. Constitutionmaking entails disagreement and compromise by stakeholders who have the right to insist upon compromise as the price of their assent. Moreover, the U.S. Constitution itself represents "a bundle of compromises" and, in the particular area of interest here, quite elaborately spells out the means by which power is to be divided between the federal and state governments. Indeed, emphasizing that federalism was an innovation of our Constitution, this Article maintains that the specific means chosen to implement our form of concurrent sovereignty in fact define the concept of federalism and that, contrary to the Court's recent cases, there is no freestanding federalism.
\end{abstract}

Since the advent of the Rehnquist Court, the Supreme Court's most distinctive mark in constitutional law has been its revival of meaningful federalism constraints on the exercise of federal power prescribed by Acts of Congress. ${ }^{1}$ Although this trend has at times en-

\footnotetext{
* Bruce Bromley Professor of Law, Harvard Law School. I thank Bradford Clark, Michael Dorf, Richard Fallon, Daniel Farber, Vicki Jackson, William Kelley, Debra Livingston, John McGinnis, Debra Jones Merritt, Gillian Metzger, Henry Monaghan, Caleb Nelson, Martin Redish, David Shapiro, Norman Spaulding, Carlos Vázquez, and Robert Weisberg for insightful comments. I thank the participants in the Notre Dame Conference on Separation of Powers as a Safeguard of Federalism, the Northwestern Constitutional Law Colloquium, and the Stanford Legal Studies Colloquium for clarifying discussions of the paper. I am grateful to Christopher Bates, Michael McGinley, and Saritha Tice for outstanding research assistance.

1 See Lynn A. Baker \& Mitchell N. Berman, Getting Off the Dole: Why the Court Should Abandon Its Spending Doctrine, and How a Too-Clever Congress Could Provoke It To Do So, 78 IND. L.J. 459, 460 (2003); Thomas W. Merrill, The Making of the Second Rehnquist Court: A Preliminary Analysis, 47 ST. LOUIS U. L.J. 569, 570 (2003); Ernest A. Young, The Rehnquist Court's
} 
tailed the interpretation of particular constitutional texts - such as the Commerce Clause ${ }^{2}$ or Section 5 of the Fourteenth Amendment ${ }^{3}-$ a subset of cases, which I will call the "new federalism" cases, instead enforce what might be termed unenumerated states' rights. In developing several important doctrines - a strict clear statement rule that restricts Congress's ability to disturb the "federal-state balance," 4 a norm against commandeering state legislative or executive officials to enforce federal law, ${ }^{5}$ and a prohibition against Congress's authorizing suits against states in state courts ${ }^{6}$ - the Court has restricted or displaced Acts of Congress without purporting to ground its decisions in any particular provision of the constitutional text. ${ }^{7}$

This is not to say that the Court in these cases forswears the constitutional text altogether. On the contrary, as is often true in matters of first impression, much of the Court's reasoning starts from the distinctly interpretivist premise that, in exercising judicial review, it must root its holding as best it can in decisions attributable to those who adopted the document pursuant to accepted constitutionmaking processes - that is, in some version of original understanding or intent. ${ }^{8}$

Two Federalisms, 83 TEX. L. REV. I, 23 (2004). This development has been uneven in some respects. In practice, while the Court has articulated and enforced robust federalism principles through aggressive statutory clear statement rules and judicial review, it has also during the same period been quite willing to find that federal regulatory statutes preempt state law — often by implication rather than by virtue of express preemption clauses. See Daniel J. Meltzer, The Supreme Court's Judicial Passivity, 2002 SUP. CT. REV. 343, 376.

2 See United States v. Morrison, 529 U.S. 598 (2000) (invalidating § I398I of the Violence Against Women Act on Commerce Clause grounds); United States v. Lopez, 5 I4 U.S. 549 (I995) (striking down the Gun-Free School Zones Act as exceeding Congress's Commerce Power).

3 See, e.g., City of Boerne v. Flores, 52 I U.S. 507, 520 (I997) (adopting a "congruence and proportionality" test to measure the validity of legislation enacted under Section 5); Bd. of Trs. of the Univ. of Ala. v. Garrett, 53 I U.S. 356, 365 (200I) (applying that test); Kimel v. Fla. Bd. of Regents, 528 U.S. $62,82-83$ (2000) (same).

4 See Gregory v. Ashcroft, 50I U.S. 452, 460 (I99I) (requiring a clear statement of legislative intent before interpreting a statute "to alter the usual constitutional balance between the States and the Federal government" (quoting Atascadero State Hosp. v. Scanlon, 473 U.S. 234, 242 (I985)) (internal quotation marks omitted)); see also, e.g., BFP v. Resolution Trust Corp., 5 I I U.S. 53 I, 544 (I 994) (requiring a "clear and manifest" intent to "displace traditional state regulation" of property foreclosure sales in the context of enforcing federal bankruptcy law); Will v. Mich. Dep't of State Police, 49I U.S. 58 (I989) (applying the federalism clear statement rule to make clear that a state is not a "person" within the meaning of 42 U.S.C. $\S$ I 983 ).

5 See Printz v. United States, 52 I U.S. 898, 918-25 (I997) (holding that "[o]ur system of dual sovereignty," $i d$. at 923 n.I3, is incompatible with the commandeering of state executive officials to implement the gun control and registration provisions of the Brady Bill); New York v. United States, 505 U.S. I44, I62 (I992) (explaining that "the Constitution has never been understood to confer upon Congress the ability to require the States to govern according to Congress' instructions").

6 See Alden v. Maine, 527 U.S. 706 (I999) (holding that state sovereign immunity shields states from being sued for money damages, even in state court).

7 See infra Part II, pp. 2020-36.

8 See infra Part II, pp. 2020-36; sources cited infra note I57. 
But what makes the new federalism decisions so interesting is that the Court seeks the founders' decisions not in the meaning of any discrete clause, but in the overall system of government they adopted in the document. This technique, a form of structural inference, identifies numerous discrete provisions that, in particular ways, divide sovereign power between state and federal governments and, in so doing, preserve a measure of state autonomy. Taking all of those provisions together, the Court ascribes to the document as a whole a general purpose to preserve a significant element of state sovereignty. From that starting premise, the Court tries to imagine, based on a combination of historical inferences and its own sense of the minimum elements of sovereignty, how the founders would have wanted to restrict Congress's power over the states, even when the founders did not reduce their (imputed) expectations or wishes to any concrete form in the constitutional text.

Of course, the Court's practice of deriving and enforcing textually unspecified principles of federalism is not new in our history; indeed, it was quite prevalent before the Court in I937 ratified the New Deal by receding from vigorous enforcement of federalism principles. ${ }^{9}$ However, the modern practice stands out, in part, because its underlying interpretive approach - strong purposivism - contrasts sharply with methodological assumptions that the Court has, in the same period, strongly embraced in its statutory interpretation cases. Traditionally, in statutory as well as constitutional cases, the Court had asserted the power to interpret specific texts to effectuate their overall "spirit," even when the results did not sit within the "letter" of the law. ${ }^{10}$ The modern Court, however, adheres more strictly to a statute's conventional semantic meaning (the letter), even when that meaning does not capture the statute's apparent purpose (spirit). ${ }^{11}$ This renewed emphasis - often, but by no means exclusively, associated with the "new textualism"12 — builds on the idea that legislation entails compromise. ${ }^{13}$ Quite apart from the reality that legislation often has cross-cutting or even conflicting aims, the fact is that no statute pursues its main pur-

\footnotetext{
9 See infra notes $82-83$ and accompanying text.

10 Church of the Holy Trinity v. United States, I43 U.S. 457, 459 (I892). This premise supplied the rule of decision in many a case. See, e.g., Pub. Citizen v. U.S. Dep't of Justice, 49I U.S. 440, 452-54 (I989); Cal. Fed. Sav. \& Loan Ass'n v. Guerra, 479 U.S. 272, 284 (I987); Anderson Bros. Ford v. Valencia, 452 U.S. 205, 222 n.20 (I98I); United Steelworkers v. Weber, 443 U.S. I93, 20I-02 (I979); Train v. Colo. Pub. Interest Research Group, Inc., 426 U.S. I, Io (I976); United Hous. Found., Inc. v. Forman, 42 I U.S. 837, 849 (I975); Nat'l Woodwork Mfrs. Ass'n v. NLRB, 386 U.S. 6r 2, 620 (I967); United States v. Pub. Util. Comm'n, 345 U.S. 295, 315 (I953); Johansen v. United States, 343 U.S. 427, 43 I (I952); Int'l Longshoremen's \& Warehousemen's Union v. Juneau Spruce Corp., 342 U.S. 237, 243 (1952).

11 See infra pp. 2019-20.

12 See William N. Eskridge, Jr., The New Textualism, 37 UCLA L. REV. 62 I (I990).

13 See infra pp. 2014-15.
} 
poses at all costs; because legislators choose means as well as ends, an interpreter must respect not only the goals of legislation, but also the specific choices Congress has made about how those goals are to be achieved. ${ }^{14}$ Accordingly, in recent years the Court has been reluctant to shift the level of statutory generality from the specific rules embedded in the enacted text to the general spirit that inspired them. ${ }^{15}$

The Court's technique in the new federalism cases represents the kind of generality-shifting technique that the Court's recent statutory cases reject. This matters, of course, only if one believes that the basic approach to statutory and constitutional interpretation should, in this respect, coincide. There are plenty of reasons to think that the two contexts merit different treatment. Given the age of the Constitution, perhaps today's interpreters should worry less about sticking to the detailed compromises struck by a "long dead" generation. ${ }^{16}$ Although the Constitution is meant for the ages, its details were designed for a different time and place. It is also unspeakably difficult to amend. ${ }^{17}$ Hence, a common strain of thought in constitutional law holds that interpreters should focus on the document's broad goals rather than details of the adopted text. ${ }^{18}$

Despite those concerns, the methodological premises of the modern statutory cases may be difficult to avoid if the Court wishes to justify its doctrine, as it does in the federalism cases, as the product of choices made, implicitly or explicitly, by those who adopted the Constitution according to the procedures agreed upon in Philadelphia and accepted by the ratifying conventions. The process insights developed by the Court in its statutory cases suggest that there is no meaningful sense in which the constitutionmakers or the constitutionmaking process can be said to have adopted federalism in the abstract. The goal of a federal system - including the retention by states of some significant measure

\footnotetext{
14 See infra p. 2014.

15 Although it is too early to make conclusive assessments of the Roberts Court, there is considerable evidence that the Court continues to subscribe to the premise that federal courts should adhere strictly to the clear import of the statutory text. See, e.g., Begay v. United States, I 28 S. Ct. I58I (2008) (closely parsing and strictly enforcing the text of the Armed Career Criminal Act); Hall St. Assocs., LLC v. Mattel, Inc., I28 S. Ct. I396, I404 (2008) (holding that "the text [of the Federal Arbitration Act] compels a reading of the $\S \S$ Io and I I categories as exclusive"); Boulware v. United States, I28 S. Ct. I I68, II 79 (2008) (relying on the "plain text" of the Tax Code); Ali v. Fed. Bureau of Prisons, I28 S. Ct. 83 I, 84I (2008) ("We are not at liberty to rewrite the statute to reflect a meaning we deem more desirable. Instead, we must give effect to the text Congress enacted ...." (footnote omitted)). But see Zuni Pub. Sch. Dist. No. 89 v. Dep't of Educ., i27 S. Ct. I534 (2007) (reviewing agency action, the Court began with an examination of the purpose of the Federal Impact Aid Act and only then determined that its text was sufficiently ambiguous to justify deference to the agency's interpretation).

16 For discussion of the so called "dead hand" problem, see infra pp. 2037-38.

17 See infra p. 2039.

18 See infra p. 2039.
} 
of autonomy or sovereignty ${ }^{19}$ - doubtless provided the justification for innumerable clauses. But those clauses implement that value in particular ways - by carefully enumerating federal powers, by assuring meaningful state participation in the composition and operation of the federal government, by imposing concrete restrictions on federal intrusion upon state autonomy, and by establishing lawmaking procedures designed to protect state interests. ${ }^{20}$ To be sure, not all of the relevant provisions are precisely drawn (consider the Commerce Clause, the Necessary and Proper Clause, or the Guarantee Clause); many leave room for interpretation, a task for which the overall purpose of federalism may, if sufficiently definite, provide guidance. But to say, as the Court does in its new federalism cases, that the document adopts an unspecified federalism norm ignores the fact that lawmakers — including constitutionmakers - must make hard choices about how to carry out their purposes, judgments about what the attainment of some purposes is worth in particular settings, and tradeoffs against other values.

Indeed, these observations may have particular force when it comes to American federalism. Because a system of concurrent sovereignty over the same territory was an American innovation rather than the adoption of an existing legal construct, there is a sense in which "Our Federalism" simply lacks meaning, considered apart from the way it was hammered out in the document. Along similar lines, the founders pursued not merely the goal of federalism or state autonomy, but also quite explicitly the competing goal of strengthening national authority. That felt need, of course, is why the founders called the Convention in the first place. Hence, particular provisions quite obviously did not reflect the implementation of merely one goal, but rather the accommodation of competing goals. When judges enforce freestanding "federalism," they ignore the resultant bargains and tradeoffs that made their way into the document.

This Article invokes the Court's insights about legislative compromise to call into question the methodological approach - what one might call multiclause purposivism - that the Court has deployed in its new federalism cases. Part I examines the central process insight of the modern Court's statutory jurisprudence - that the reality of legislative compromise warrants close attention to the level of generality agreed upon in the text. Part II sketches the purposive method by which the Court derived the norm of federalism in three areas of new

19 The term sovereignty has many potential connotations. See H. Jefferson Powell \& Benjamin J. Priester, Convenient Shorthand: The Supreme Court and the Language of State Sovereignty, 7 I U. COLO. L. REV. 645 (2000). I use it here to connote the power of ultimate decisionmaking discretion, free from the control of a superior political entity.

20 See infra section III.B, pp. 2048-55. 
federalism doctrine: the adoption of clear statement rules restricting the domain of statutes that disrupt a hypothetical state-federal balance; an anticommandeering principle that is not traceable to the Constitution's text; and the identification of novel forms of state sovereign immunity that similarly lack any discernible textual source. Starting from the Court's own premise that it is reconstructing decisions that can reasonably be attributed to the constitutionmaking process, Part III outlines concrete arguments for extending the methodological assumptions about compromise from the statutory cases to the interpretation of the structural elements of the original Constitution. It closes by giving brief consideration to alternative justifications for the new federalism cases.

Before turning to this analysis, it is important to make clear that this Article's aim is to use the methodology of this important line of recent federalism cases as a window into the commonalities, if any, between statutory and constitutional interpretation. It does not seek to ascertain the "original understanding" of the many discrete clauses that allocate state and federal power or to determine whether any particular decision might be justified on the basis of such an understanding. Nor does it seek to adjudicate the related question of whether older lines of cases - such as those abandoning meaningful limits on the Commerce Clause or embracing an atextual dormant commerce power - can themselves be squared with the Court's more recent, text-based approach. ${ }^{21}$ Rather, the analysis that follows focuses on the previously identified subset of new federalism cases because their evident generality-shifting purposivism coincides with the rise of the new textualism in statutory cases and thus places the methodological question in sharp relief.

\section{LETTER VERSUS SPIRIT}

Recent developments in statutory interpretation theory will help to frame an evaluation of the methodology of the Court's new federalism cases. In matters of statutory interpretation, the Court tends to divide

21 Some of the Court's textualist and textualist-leaning Justices have criticized these older lines of cases as being inconsistent with the meaning of the constitutional text. See, e.g., Camps Newfound/Owatonna, Inc. v. Town of Harrison, 520 U.S. 564, 6 Io (I997) (Thomas, J., dissenting) (arguing that the Court's dormant commerce clause jurisprudence is "overbroad because, unmoored from any constitutional text, it brought within the supervisory authority of the federal courts state action far afield from the discriminatory taxes it was primarily designed to check"); United States v. Lopez, 5 I4 U.S. 549, 585-89 (I995) (Thomas, J., concurring in the judgment) (arguing that the text of Article I, read in context, cannot support the broad post-New Deal reading of the Commerce Clause); Tyler Pipe Indus., v. Wash. State Dep't of Revenue, 483 U.S. 232, 260 (I987) (Scalia, J., concurring in part and dissenting in part) (criticizing the dormant commerce clause jurisprudence on the ground that the "text of the Clause" provides no basis for judicial enforcement in the absence of implementing legislation). 
between purposivists and textualists. Purposivists traditionally have been generality shifters; they believe that true fidelity to congressional directives requires judges to depart from specific semantic details of the enacted text when necessary to fulfill what they understand to be the statute's overall purpose. In the traditional lingo, when the "letter" of the statute conflicts with its "spirit," the spirit or purpose controls. Textualists, in contrast, are generality sticklers; they maintain that the interpreters must pay attention to the details that emerge from the legislative process, even if doing so does not fully serve, or even disserves, the statute's apparent general purpose. In the past two decades or so, the Court's center of gravity in statutory cases has shifted from the generality shifters to the generality sticklers.

The purposivist view, which dominated the Court's approach until quite recently, has much to commend it. Purposivism reasonably presupposes that Congress passes laws to achieve some aim. Because Congress necessarily legislates in haste and with limited foresight, a statute's details may not always capture its goals. So in a system premised on legislative supremacy, judges should assist legislatures by focusing on the underlying goals of the legislation. For example, if a statute bans "dogs" from the park, respect for the legislature suggests that judges should apply the statute to wolves or coyotes or other animals that present the same mischief that inspired the statute in the first place, but which the legislature might have overlooked. Purposivists thus are willing to shift the level of generality at which a statute's policy or purpose is articulated in order to achieve rational results that they presume the legislature would have wanted if it had focused on the issues before the Court.

Textualism, in contrast, emphasizes that statutes require compromise, that statutory details may reflect the product of undisclosed and undiscoverable bargains, and that the level of generality at which a statute speaks itself represents an important element of legislative choice. Treating a statute that bans "dogs" from a park as if it banned all similarly "dangerous or disruptive animals" devalues the legislative choice to opt for the more certain and specific designation of a particular species, rather than a more flexible and indefinite delegation to future executive and judicial officers to decide what kinds of animals are dangerous or disruptive. ${ }^{22}$

These two competing approaches, of course, have considerable overlap. $^{23}$ Textualists understand that statutes are enacted to serve a purpose and, when semantically ambiguous, should be construed ac-

22 The example comes from Frank H. Easterbrook, Statutes' Domains, 50 U. CHI. L. REV. 533,535 (I983).

23 See John F. Manning, What Divides Textualists from Purposivists?, Io6 CoLuM. L. REv. 70 (2006). 
cordingly. ${ }^{24}$ For their part, purposivists accept that the derivation of purpose must take the text as an important and often conclusive starting point. ${ }^{25}$ Still, the two approaches have traditionally diverged sharply in their relative willingness to shift the level of generality of a statute from its detailed implemental rules to the purposes that explain them. Because these differences sharpen the methodological stakes in the new federalism cases, the competing approaches merit brief elaboration.

\section{A. The Holy Trinity Era}

Traditionally, the Court embraced the generality-shifting tradition of purposivism. The classic exemplar of this approach is of course Church of the Holy Trinity v. United States. ${ }^{26}$ Section I of the Alien Contract Labor Act of I885 had made it a crime to contract with an alien to migrate to the United States to "perform labor or service of any kind." ${ }^{27}$ Holy Trinity Church had contracted with the Reverend E. Walpole Warren to come from England to serve as minister to a New York congregation. ${ }^{28}$ Although concluding that this contract fell squarely within the prohibition found in the Act's text, ${ }^{29}$ the Court emphasized that "a thing may be within the letter of the statute and yet not within the statute, because not within its spirit, nor within the intention of its makers." ${ }^{30}$ Although the Act speaks of "labor and service of any kind," the Court reasoned that the statute's background purpose reached only manual laborers. The Act's title only mentioned those who came "to perform labor." ${ }_{1} 1$ The circumstances surrounding the Act's passage — including the legislative history - further indicated that Congress aimed merely to prevent "the influx of . . cheap

24 See id. at $84-85$

25 See id. at $85-9$ I. Justice Frankfurter once aptly summarized this aspect of purposivism when he wrote that a statute's "aim, [its] policy is not drawn, like nitrogen, out of the air; it is evinced in the language of the statute, as read in the light of other external manifestations of purpose.” Felix Frankfurter, Some Reflections on the Reading of Statutes, 47 COLUM. L. REv. 527, 539 (I947).

26 I43 U.S. 457 (I892).

27 Id. at 458 (quoting Alien Contract Labor Act of 1885 , ch. I64, § I, 23 Stat. 332, 332 (repealed $\left.\left.195^{2}\right)\right)$.

28 Id. at $457-58$.

29 See id. at $45^{8-59}$ ("It must be conceded that the act of the corporation is within the letter of this section, for the relation of rector to his church is one of service, and implies labor on the one side with compensation on the other. Not only are the general words labor and service both used, but also, as it were to guard against any narrow interpretation and emphasize a breadth of meaning, to them is added 'of any kind'; and, further, ... the fifth section [of the statute], which makes specific exceptions, among them professional actors, artists, lecturers, singers and domestic servants, strengthens the idea that every other kind of labor and service was intended to be reached by the first section.").

$30 I d$. at 459 .

31 Id. at 463 . 
unskilled labor." 32 The Court therefore found it appropriate to shift the level of generality at which the statute expressed its policy from the broader level expressed in the letter of the statutory text (to prevent contracts for the importation of "labor or service of any kind") to the narrower purpose that apparently explained the statute's enactment (to address only manual labor). Given the apparent clarity of the background purpose, the Court assumed that the drafters of Section I had "unexpectedly ... reach[ed] cases and acts which ... could not have been intentionally legislated against." 33 For the Court, therefore, narrowing the level of statutory generality from that expressed by the enacted text was simply not "the substitution of the will of the judge for that of the legislator," ${ }^{34}$ but rather a faithful application of the legislator's will.

The generality-shifting premises implicit in Holy Trinity described the dominant attitude for much of the twentieth century. Perhaps the most influential statutory interpretation decision of that century United States v. American Trucking Ass'ns ${ }^{35}$ - made clear that when a particular statutory provision produced a result "plainly at variance with the policy of the legislation as a whole,"36 federal judges properly "followed that purpose, rather than the literal words." 37 Twentieth century legal scholars, moreover, developed a justification for that approach that tied it closely to the notion of legislative supremacy: Congress passes statutes to achieve some purpose, and interpreters concerned with legislative supremacy should act on that basis. ${ }^{38}$ Professor Max Radin thus wrote that "[t]he legislature that put [a] statute on the books had the constitutional right and power to set [the statute's] purpose as a desirable one for the community, and the court or administrator has the undoubted duty to obey it." 39 Because the drafter selected the words "primarily to let us know the statutory purpose," interpreters must proceed with that function in mind. ${ }^{40}$ Hence, "if the

\footnotetext{
32 Id. at 465.

33 Id. at 472 .

34 Id. at 459 .

353 I 0 U.S. 534 (1940)

36 Id. at 543 (quoting Ozawa v. United States, 260 U.S. I78, I94 (I922)) (internal quotation marks omitted).

37 Id. (citing Helvering v. Morgan's, Inc., 293 U.S. I2 I, I 26 (I934)).

38 See, e.g., Archibald Cox, Judge Learned Hand and the Interpretation of Statutes, 60 HARV. L. REV. 370, 370 (I947) (noting that some "purpose lies behind all intelligible legislation"); Frankfurter, supra note 25 , at 538-39 ("Legislation has an aim; it seeks to obviate some mischief, to supply an inadequacy, to effect a change of policy, to formulate a plan of government.").

39 Max Radin, A Short Way with Statutes, 56 HARV. L. REV. 388, 398 (I942).

40 Id. at 400 . He elaborated as follows:

To say that the legislature is "presumed" to have selected its phraseology with meticulous care as to every word is in direct contradiction to known facts and injects an improper element into the relation of courts to the statutes. The legislature has no constitutional warrant to demand reverence for the words in which it frames its directives. If the pur-
} 
purpose is clear, the implemental part of the statute should be subordinated to it." 41 Ultimately, that idea became the underpinning of the singularly influential Legal Process materials, in which Professors Henry Hart and Albert Sacks of Harvard Law School wrote that an interpreter must "[d]ecide what purpose ought to be attributed to the statute and to any subordinate provision of it which may be involved; and then ... [i]nterpret the words of the statute immediately in question so as to carry out the purpose as best it can." 42 Starting from the related presumption "that the legislature was made up of reasonable persons pursuing reasonable purposes reasonably," they urged judges to smooth out the rough spots in statutes and to supply needed omissions. ${ }^{43}$ The purposive approach expressed by Hart and Sacks supplied the reigning ideology of statutory interpretation until almost the end of the twentieth century. ${ }^{44}$

\section{B. The New Textualism}

Near the end of the twentieth century, the Court adopted the more text-based approach to statutory interpretation that it tends to use today. Although textualism is perhaps most commonly associated with an effort to reduce or eliminate judicial reliance on legislative history, ${ }^{45}$ the aspect of greater interest here relates to the Court's new propensity to favor letter over spirit when the two conflict. This latter feature has proven more successful than the resistance to legislative history and,

poses of the statute cannot be learned except by examining the precise words and by troubling our ingenuity to discover why this word was used rather than another of approximately similar effect, then this process of anxious cogitation must be employed. But it is rarely necessary.

Id. at 406 .

41 Id. at 407 .

42 Henry M. Hart, Jr. \& Albert M. Sacks, The Legal Process i374 (William N. Eskridge, Jr. \& Philip P. Frickey eds., I994) (1958).

43 Id. at $\mathrm{I} 378$.

44 See, e.g., T. Alexander Aleinikoff, Updating Statutory Interpretation, 87 MiCH. L. REv. 20, 26-28 (I 988) (discussing the intellectual influence of the Hart and Sacks materials); William N. Eskridge, Jr. \& Philip P. Frickey, Legislation Scholarship and Pedagogy in the Post-Legal Process Era, 48 U. PITT. L. REV. 69I, 698-99 (I987) (same).

45 See Stephen Breyer, On the Uses of Legislative History in Interpreting Statutes, 65 S. CAL. L. REV. 845 (I992) (criticizing the Court's increasing reluctance to use legislative history and suggesting reasonable uses of legislative history); Eskridge, supra note I2, at 656-58 (discussing the influence of textualism on tools of construction); Thomas W. Merrill, Textualism and the Future of the Chevron Doctrine, 72 WASH. U. L.Q. 35 I, 355-6I (I994) (discussing the diminished use of legislative history by the Rehnquist Court and the textualist approach to resolving ambiguity through dictionaries and semantic canons); Patricia M. Wald, The Sizzling Sleeper: The Use of Legislative History in Construing Statutes in the 1988-89 Term of the United States Supreme Court, 39 AM. U. L. REV. 277, 279-300 (I990) (compiling data on the declining use of legislative history during the I $980 \mathrm{~s}$ ). 
as discussed below, has been assimilated to a surprising extent by nontextualists. ${ }^{46}$

In the past two decades, the Court has moved from the routine invocation of Holy Trinity to an approach that resists stretching or contracting a specific text to fit its background purpose. ${ }^{47}$ The rationale is this: shifting the level of generality of a statute from its implemental details to its purpose disregards the reality that enacted laws, by and large, represent the end-product of compromises which may not fully capture the background purpose that motivated the enactment. The idea began to take shape just before the advent of the Rehnquist Court, when a unanimous Court in Board of Governors of the Federal Reserve System v. Dimension Financial Corp. ${ }^{48}$ observed:

Congress may be unanimous in its intent to stamp out some vague social or economic evil; however, because its Members may differ sharply on the means for effectuating that intent, the final language of the legislation may reflect hard-fought compromises. Invocation of the "plain purpose" of legislation at the expense of the terms of the statute itself takes no account of the processes of compromise ... 49

In other words, favoring the legislative spirit or purpose over the plain terms of a statute does not supply a superior means of capturing the result the legislature meant to adopt, but rather risks disregarding the fact that members of Congress must sometimes accept half a loaf in order to get legislation through a complex process with multiple veto points.

During the closing years of the twentieth century, this idea took root in the Court's opinions. The development doubtless reflected the influence of Justices Scalia, Kennedy, and Thomas, who are either openly textualist in their approach (Scalia) or at least sympathetic to its premises (Kennedy and Thomas). Justice Scalia thus wrote for the Court that judges may not base interpretations on "policy arguments" when they contradict the conventional import of the enacted text, "which may, for all we know, have slighted policy concerns on one or the other side of the issue as part of the legislative compromise that enabled the law to be enacted." 50 Justice Kennedy likewise explained for the Court that "any key term in an important piece of legislation" typically reflects "the result of compromise between groups with marked but divergent interests in the contested provision" and that "[c]ourts and agencies must respect and give effect to these sorts of

\footnotetext{
46 See infra p. 2015.

47 Holy Trinity's last favorable citation in an opinion of the Court was in Public Citizen v. U.S. Department of Justice, 49I U.S. 440, 454 (1989).

48474 U.S. 36 I (I986).

49 Id. at 374 .

50 Artuz v. Bennett, 53 I U.S. 4, Io (2000).
} 
compromises." ${ }_{1}$ And in the course of rejecting a rather compelling purposive argument for departing from the clear terms of a complex regulatory statute, Justice Thomas stated for the Court:

Dissatisfied with the text of the statute, the [petitioner] attempts to search for and apply an overarching legislative purpose to each section of the statute. Dissatisfaction, however, is often the cost of legislative compromise. And negotiations surrounding enactment of this bill tell a typical story of legislative battle among interest groups, Congress, and the President. ... Its delicate crafting reflected a compromise amidst highly interested parties attempting to pull the provisions in different directions. As such, a change in any individual provision could have unraveled the whole. It is quite possible that a bill that assigned liability [in a different way] would not have survived the legislative process. The deals brokered during a Committee markup, on the floor of the two Houses, during a joint House and Senate Conference, or in negotiations with the President ... are not for us to judge or second-guess. ${ }^{52}$

Equally striking, for present purposes, is the fact that these process assumptions gained significant traction among Justices who would not remotely describe themselves as textualists. ${ }^{53}$ Justice O'Connor thus wrote for the Court that "[g]iving full effect to the words of the statute preserves the compromise struck by Congress." ${ }^{54}$ Justice Marshall similarly observed that "[s]trict adherence to the language and structure of the Act is particularly appropriate where, as here, a statute is the result of a series of carefully crafted compromises." ${ }_{55}$ And Justice Blackmun spoke for eight Justices when he stated:

$[\mathrm{N}]$ o legislation pursues its purposes at all costs. Deciding what competing values will or will not be sacrificed to the achievement of a particular objective is the very essence of legislative choice - and it frustrates rather than effectuates legislative intent simplistically to assume that whatever furthers the statute's primary objective must be the law. ${ }^{56}$

Behind these statements lies the major premise that rules of interpretation should try to discern the meaning agreed upon through the prescribed legislative process by those authorized to pass legislation under our system of government. ${ }^{57}$ If one accepts that starting point, then the Court's new approach reflects straightforward assumptions

\footnotetext{
51 Ragsdale v. Wolverine World Wide, Inc., 535 U.S. 81, 93-94 (2002) (citing Mohasco Corp. v. Silver, 447 U.S. 807, 818-19 (I980)).

52 Barnhart v. Sigmon Coal Co., 534 U.S. 438, 46I (2002) (citations omitted).

53 See Jonathan T. Molot, The Rise and Fall of Textualism, ro6 Colum. L. REV. I, 32-33 (2006) (describing increasing reliance on the text by purposivist Justices).

54 Hallstrom v. Tillamook County, 493 U.S. 20, 29 (I989).

55 Cmty. for Creative Non-Violence v. Reid, 490 U.S. 730,748 n.I4 (I989).

56 Pension Benefit Guar. Corp. v. LTV Corp., 496 U.S. 633, 646-47 (I990) (alteration in original) (quoting Rodriguez v. United States, 480 U.S. 522, 525-26 (I987) (per curiam)) (internal quotation marks omitted).

57 See infra note 156.
} 
about the legislative process. Lawmaking in our system is complex and path dependent. The bicameralism and presentment requirements of Article I give political minorities extraordinary power to block legislative change or to insist upon compromise as the price of assent. ${ }^{58}$ In addition, the legislative procedures adopted by each House - including, most notably, committee gatekeeping, the Senate filibuster, and the Senate's unanimous consent requirement - further enhance the protection of such minorities. ${ }^{59}$ Accordingly, the legislative process does not permit the majority to translate its general policy preferences seamlessly into specific statutory commands, but rather necessitates compromise. And any theory of interpretation that rests on a theory of the legislative process must deal with that reality, as the Court's recent cases consciously do.

Strongly purposivist interpretation risks disturbing those process commitments in three overlapping ways. First, reliance on purpose threatens to upset necessary legislative compromises because it arbitrarily shifts the level of generality at which the lawmakers have expressed their policy. This insight is implicit in much of the Court's recent case law, but the most cogent account of the problem was supplied by then-legal realist Professor Radin (writing before his conversion to purposivism). ${ }^{60} \mathrm{He}$ wrote that statutes surely are enacted for a purpose and that "it is rare indeed that we can not say positively what any particular statute is for, by reading it." ${ }_{1}$ He added, however, that "nearly every end is a means to another end" and that, if one carries the idea far enough, "the avowed and ultimate purposes of all statutes, because of all law, are justice and security."62 Accordingly,

58 See James M. Buchanan \& Gordon Tullock, The Calculus of Consent: LOGiCAL Foundations of CONSTITUTIONAL DEMOCRACY 233-48 (ig62) (making this point about bicameralism even when the two houses are the same size). Indeed, by requiring equal representation of states in the Senate, the Constitution explicitly protects the political minority made up of small-state residents. See U.S. ConsT. art. I, § 3, cl. I; see also id. art. V ("[N]o State, without its Consent, shall be deprived of its equal Suffrage in the Senate."); Bradford R. Clark, Separation of Powers as a Safeguard of Federalism, 79 TEX. L. REV. I32 I, I37 I-72 (200I) (discussing this feature of the Constitution).

59 See, e.g., Kenneth A. Shepsle \& Barry R. Weingast, The Institutional Foundations of Committee Power, 8I AM. POL. SCI. REV. 85, 89 (I987) (noting, in general, that "veto groups are pervasive in legislatures" and, in particular, that "[a] small group of senators ... may engage in filibuster and other forms of obstruction" and "[a]ny individual senator may refuse unanimous consent to procedures that would expedite passage of a committee bill”). Although scholars debate whether standing committees ultimately represent the preferences of the chamber they serve, a good deal of evidence supports the view that many such committees are imperfectly representative of their chamber. See, e.g., John R. Boyce \& Diane P. Bischak, The Role of Political Parties in the Organization of Congress, I8 J.L. ECON. \& ORG. I, 2-3 (2002) (summarizing the scholarly debate).

60 For discussion of Radin's purposive philosophy, see supra pp. 2012-I3.

61 Max Radin, Statutory Interpretation, 43 HARV. L. REV. 863, 876 (I930).

$62 I d$. 
when an interpreter moves from the immediate meaning of the adopted text to the background purposes that explain it, the level of generality selected by the interpreter reflects an unavoidable element of arbitrariness. ${ }^{63}$

Second, when a court interprets a statute according to its background purpose rather than the specific terms embodied in the text, that court discounts the reality that legislators bargain over means as well as ends. Judge Easterbrook has articulated this point with particular clarity. He writes: "[L]aw is like a vector. It has length as well as direction. We must find both, or we know nothing of value. To find length we must take account of objectives, of means chosen, and of stopping places identified." 64 Judge Easterbrook thus maintains that purposivism disturbs legislative compromise by transforming all means-specifying rules into goal-oriented standards:

A legislature that seeks to achieve Goal $X$ can do so in one of two ways. First, it can identify the goal and instruct courts or agencies to design rules to achieve the goal. In that event, the subsequent selection of rules implements the actual legislative decision, even if the rules are not what the legislature would have selected itself. The second approach is for the legislature to pick the rules. It pursues Goal $X$ by Rule $Y$. The selection of $Y$ is a measure of what Goal $X$ was worth to the legislature, of how best to achieve $X$, and of where to stop in pursuit of $X$. Like any other rule, $Y$ is bound to be imprecise, to be over- and under-inclusive. This is not a good reason for a court, observing the inevitable imprecision, to add to or subtract from Rule $Y$ on the argument that, by doing so, it can get more of Goal $X$. The judicial selection of means to pursue $X$ displaces and directly overrides the legislative selection of ways to obtain $X$. It denies to legislatures the choice of creating or withholding gapfilling authority. ${ }^{65}$

Accordingly, when purposivists rely on "an imputed 'spirit' to convert one approach into another," they "dishonor[] the legislative choice as effectively as expressly refusing to follow the law." 66

Third, statutes may have multiple purposes that do not point neatly in one direction. Perhaps the Court's staunchest purposivist, Justice Stevens, thus wrote for the Court not long ago: "Statutes are seldom crafted to pursue a single goal, and compromises necessary to their en-

63 See id. at 878 ("[T] interpret a law by its purposes requires the court to select one of a concatenated sequence of purposes, and this choice is to be determined by motives which are usually suppressed."); see also Stephen F. Williams, Rule and Purpose in Legal Interpretation, 6 I U. COLO. L. REV. 809, 8I I (I990) ("Notice that as soon as the analysis of purpose is divorced from the means selected, all limits are off. Every purpose can always be restated at a higher level of generality.").

64 Frank H. Easterbrook, The Role of Original Intent in Statutory Construction, I I HARV. J.L. \& PUB. POL'Y 59, 63 (I988).

65 Easterbrook, supra note 22, at 546-47 (footnotes omitted).

66 Frank H. Easterbrook, Text, History, and Structure in Statutory Interpretation, I 7 HARV. J.L. \& PUB. POL'Y 6I, 68 (I994). 
actment may require adopting means other than those that would most effectively pursue the main goal." ${ }_{7}$ Accordingly, the Court has made clear that "[d]eciding what competing values will or will not be sacrificed to the achievement of a particular objective is the very essence of legislative choice." 68

To draw the contrast more sharply, I have underscored the distinctions between the two approaches. But they should not be overstated. The belief that interpreters should not read rule-based texts as if they adopted purposive standards does not mean textualists view all statutes as comprehensive rule books, whose meanings are evident on their face. Textualists do not deny that legislation inevitably encompasses areas of indeterminacy, sometimes significant ones that reflect an implicit or explicit legislative choice to delegate to interpreters authority over policy details. ${ }^{69}$ Nor do they deny that statutes have purposes sometimes readily apparent ones - that interpreters may properly consult when resolving ambiguity in a statutory text. ${ }^{70}$ And because textualists acknowledge that language has meaning only in a rich social and linguistic context, they understand that there is no selfapplying metric for deciding when the "letter" of the law is clear enough to foreclose consideration of the "spirit." 71

These qualifications, however, do not detract from the process assumptions that have gained traction with the Court over the past two decades. Although textualists recognize (in contrast with their forbears in the "plain meaning" school) that interpretation is not mechanical, they believe that legislators can communicate effectively with judges, administrators, and the public because of their common membership in a linguistic community with shared practices for understanding a

\footnotetext{
67 Landgraf v. USI Film Prods., 5 I I U.S. 244, 286 (1994).

68 Rodriguez v. United States, 480 U.S. 522, 526 (1987) (per curiam).

69 See, e.g., Mistretta v. United States, 488 U.S. 36I, 4I 7 (I989) (Scalia, J., dissenting) (noting that "it is up to Congress, by the relative specificity or generality of its statutory commands, to determine - up to a point - how small or how large [the] degree [of interstitial lawmaking] shall be"); NBD Bank, N.A. v. Bennett, 67 F.3d 629, 633 (7th Cir. I995) (Easterbrook, J.) ("No Member of Congress can anticipate all questions that will come to light; and a body containing hundreds of members with divergent agendas can't answer even a small portion of the questions that do occur to its members. That is one reason why Congress frequently delegates power to executive officials ....").

70 See, e.g., Asgrow Seed Co. v. Winterboer, 5 I3 U.S. I79, I92 (I995) (Scalia, J.) ("While the meaning of the text is by no means clear, this is in our view the only reading that comports with the statutory purpose ...."); Nat'l Tax Credit Partners, L.P. v. Havlik, 20 F.3d 705, 707 (7th Cir. I994) (Easterbrook, J.) ("Knowing the purpose behind a rule may help a court decode an ambiguous text, but first there must be some ambiguity." (citations omitted) (citing, inter alia, Sundstrand Corp. v. Comm'r, I7 F.3d 965, 967 (7th Cir. I994); Lincoln v. Vigil, 508 U.S. I82, I 91-94 (I993))).

71 See William N. Eskridge, Jr., Textualism, The Unknown Ideal?, 96 Mich. L. REv. I509, I5 8 (I998) (reviewing ANTONIN SCALIA, A MATTER OF INTERPRETATION (Amy Gutmann ed., 1997)) (arguing that there is typically room for disagreement about whether a text is clear, when considered in its full context).
} 
vast array of words and phrases in context. ${ }^{72}$ If one accepts that premise, then it follows that legislators can effectively articulate their policies at varying levels of generality - to choose whether to regulate "dogs" or "canines" or "dangerous animals." What the Court's recent cases have emphasized is that the statutory level of generality itself sends an important signal about what the legislature decided; hence, rules should not be converted to standards, nor standards to rules. The Court thus regards itself as "bound, not only by the ultimate purposes Congress has selected, but by the means it has deemed appropriate, and prescribed, for the pursuit of those purposes." 73 It recognizes "that the reach of a statute often exceeds the precise evil to be eliminated" and that "it is not, and cannot be, [the Court's] practice to restrict the unqualified language of a statute to the particular evil that Congress was trying to remedy - even assuming that it is possible to identify that evil from something other than the text of the statute itself." 74 And even if the Court thinks it clear that a statute's drafters would not have wished the statute to apply to a set of unforeseen circumstances, "in the context of an unambiguous statutory text that is irrelevant." 75 In short, because of a growing emphasis on the

72 See, e.g., Jeremy Waldron, Legislators' Intentions and Unintentional Legislation, in LAW AND INTERPRETATION 329, 339 (Andrei Marmor ed., 1995) ("A legislator who votes for (or against) a provision like 'No vehicle shall be permitted to enter any state or municipal park' does so on the assumption that - to put it crudely — what the words mean to him is identical to what they will mean to those to whom they are addressed .... That such assumptions pervade the legislative process shows how much law depends on language, on the shared conventions that constitute a language, and on the reciprocity of intentions that conventions comprise."). That assumption about communication is not universally shared. See, e.g., James Boyle, The Politics of Reason: Critical Legal Theory and Local Social Thought, I33 U. PA. L. REV. 685, 708-I I, 728 (I985) (contending that the linguistic formulations of legal rules are indeterminate); Joseph William Singer, The Player and the Cards: Nihilism and Legal Theory, 94 YALE L.J. I, I9 (1984) (arguing that rules "generally do not determine the scope of their own application"). The Court, however, starts from the assumption that texts are sometimes determinate in context, and I start here from the Court's assumptions. See John F. Manning, The Absurdity Doctrine, I I6 HARV. L. REV. 2387,2397 n.30 (2003). For a detailed defense of the underlying proposition, see FrEDERick Schauer, Playing by the Rules: A Philosophical Examination of RuleBASED DECISION-MAKING IN LAW AND IN LIFE 64-68 (I99I), which defends the possibility of the linguistic determinacy of legal rules in an established language.

73 MCI Telecomms. Corp. v. AT\&T Co., 5 I 2 U.S. 2 I 8, 23 I n.4 (I994) (Scalia, J.).

74 Brogan v. United States, 522 U.S. 398, 403 (I 998 ) (Scalia, J.).

75 Pa. Dep't of Corr. v. Yeskey, 524 U.S. 206, 2 I 2 (I998) (Scalia, J.); see also, e.g., Oncale v. Sundowner Offshore Servs., Inc., 523 U.S. 75, 79 (I998) (Scalia, J.) ("[S]tatutory prohibitions often go beyond the principal evil to cover reasonably comparable evils, and it is ultimately the provisions of our laws rather than the principal concerns of our legislators by which we are governed."); W. Va. Univ. Hosps., Inc. v. Casey, 499 U.S. 83, 98 (I99I) (Scalia, J.) (noting that "the purpose of a statute includes not only what it sets out to change, but also what it resolves to leave alone," and that "[t]he best evidence of that purpose is the statutory text adopted by both Houses of Congress and submitted to the President" (citation omitted)). 
inevitable role of compromise in translating legislative ends into statutory means, the Court has become much less of a generality shifter and much more of a generality stickler in matters of statutory interpretation.

\section{THE NEW FEDERALISM}

The Court's new federalism cases represent an obvious effort to reassert constraints on Congress's Article I powers without restoring the full array of limitations that it had applied prior to its 1937 acquiescence in the New Deal's expansion of federal power. ${ }^{76}$ Those earlier constraints were significant, even if unevenly applied. First, and most important, the pre-New Deal Court relied primarily on a set of doctrines that purported to implement Congress's Article I authority to regulate "Commerce... among the several States." cases did not follow a straight line, ${ }^{78}$ the Court sought to identify formal categories separating "commerce" from activities such as manufacturing, ${ }^{79}$ to restrict federal regulation to activities having a "direct" ef-

76 See, e.g., David P. Currie, The Constitution in the Supreme Court: The SeCOND CENTURY, I888-1986, at 236-38 (I990) (articulating the conventional wisdom that the Court experienced a change in attitude that resulted in the abandonment of constraints on federal power in 1937). For the argument that the Hughes Court's approach to the New Deal showed more continuity than conventional wisdom holds and that the Court's relaxation of constraints on the Commerce Power came somewhat later (after President Roosevelt had secured a few appointments), see Barry Cushman, Rethinking the New Deal Court: The StrucTURE OF A CONSTITUTIONAL REVOLUTION (I998). For present purposes, it does not matter whether the shift occurred in 1937 or thereafter.

77 U.S. CONST. art. I, $\S 8$, cl. 3 .

78 For an excellent account of the unevenness of the Court's pre-New Deal federalism jurisprudence, see Robert Post, Federalism in the Taft Court Era: Can It Be "Revived"?, 5 I DukE L.J. I5 I3 (2002).

79 The most prominent of such cases, United States v. E.C. Knight Co., I56 U.S. I (1895), held that the Congress could not prohibit the monopolization of sugar refining, even though the end product of that manufacturing process entered the stream of commerce. Id. at I2. The Court famously wrote:

Doubtless the power to control the manufacture of a given thing involves in a certain sense the control of its disposition, but this is a secondary and not the primary sense, and although the exercise of that power may result in bringing the operation of commerce into play, it does not control it, and affects it only incidentally and indirectly. Commerce succeeds to manufacture, and is not a part of it. The power to regulate commerce is the power to prescribe the rule by which commerce shall be governed, and is a power independent of the power to suppress monopoly.

Id.; see also, e.g., United Mine Workers v. Coronado Coal Co., 259 U.S. 344, 407 (I922) ("Coal mining is not interstate commerce, and the power of Congress does not extend to its regulation as such.”). Other cases, however, made the line somewhat fuzzier than the language in E.C. Knight suggested. For example, in Swift \& Co. v. United States, I96 U.S. 375 (1905), the Court held that federal law could regulate a merger of manufacturing concerns where the government could show "intent ... to aid in an attempt to monopolize commerce among the States." Id. at 398. More strikingly, the pre-New Deal Court upheld Congress's decision to preempt state regulation of purely intrastate rail service on the premise that doing so was necessary to protect the financial 
fect upon interstate commerce, ${ }^{80}$ and to limit the clause to its apparent purpose of authorizing regulation of interstate commerce as such (as opposed to regulation of such commerce to achieve desirable social ends in intrastate matters). ${ }^{81}$ Second, the Court invoked the Tenth Amendment to implement an unenumerated doctrine of "dual federalism" - the idea that the Constitution reserves to the states some unspecified realm of exclusive sovereign authority, even as to matters that would otherwise fall within a grant of federal lawmaking power. ${ }^{82}$

health of interstate railroads. See R.R. Comm'n v. Chi., Burlington \& Quincy R.R. Co., 257 U.S. 563, 585-86 (1922). In so holding, Chief Justice Taft wrote for the Court: "Commerce is a unit and does not regard state lines." Id. at 588 ; see also, e.g., Bd. of Trade v. Olsen, 262 U.S. I, 32 (I923) (upholding federal regulation of intrastate commodities trading transactions because Congress found that "by manipulation they have become a constantly recurring burden and obstruction to that interstate commerce"); Stafford v. Wallace, 258 U.S. 495, 52 I (I922) (upholding the Packers and Stockyards Act of I92 I on the ground that regulating the local economic activity in question would prevent "conspiracies against interstate commerce or . . . a direct and undue burden against it"). For an excellent account of the complexities of the Court's line drawing on such matters in the years leading up to the New Deal, see Post, supra note 78 , at ${ }_{5} 538-58$.

80 See, e.g., A.L.A. Schechter Poultry Corp. v. United States, 295 U.S. 495, 546 (I935) ("In determining how far the federal government may go in controlling intrastate transactions upon the ground that they 'affect' interstate commerce, there is a necessary and well-established distinction between direct and indirect effects.").

81 Most notoriously, the Court held that Congress could not prohibit the interstate sale of goods made with child labor, reasoning that "[t]he act in its effect does not regulate transportation among the states, but aims to standardize the ages at which children may be employed in mining and manufacturing within the States.” Hammer v. Dagenhart, 247 U.S. 25 I, 27 I-72 (I9I8). At the same time, the Court upheld a variety of statutes that used the hook of interstate commerce or transportation to get at intrastate activity. See, e.g., Brooks v. United States, 267 U.S. 432, 436-39 (I925) (upholding the National Motor Vehicle Theft Act, which made it a crime to transport a stolen vehicle in interstate commerce); Hoke v. United States, 227 U.S. 308 (I9I3) (upholding federal statute prohibiting the transportation of women across state lines for "immoral purposes").

82 The classic account of this phenomenon is found in Edward S. Corwin, The Passing of Dual Federalism, 36 VA. L. REV. I (I950). The implied reservation under the Tenth Amendment of state police power over internal affairs provides an alternative explanation for the holding in Hammer, 247 U.S. at 275 , which stated that: "The power of the States to regulate their purely internal affairs by such laws as seem wise to the local authority is inherent and has never been surrendered to the general government." Bailey v. Drexel Furniture Co., 259 U.S. 20 (I 922 ), offers a more obvious example. There, the Court held that Congress could not invoke its taxing power to impose a tax on goods made with child labor because such a tax, although otherwise valid, would invade a sphere of police power reserved to the states by the Tenth Amendment. See id. at 38 (arguing that permitting Congress to use the taxing power to achieve such ends would be "to take over to its control any one of the great number of subjects of public interest, jurisdiction of which the States have never parted with, and which are reserved to them by the Tenth Amendment").

During this period, the Court also implemented a doctrine of state sovereign immunity, which was not traceable to a straightforward reading of the constitutional text. See, e.g., Hans v. Louisiana, I34 U.S. I, IO-I I (I890) (relying on the purposes of the Eleventh Amendment to extend sovereign immunity beyond the terms specified by the amendment); see also infra pp. 203234. In addition, the Court enforced various idiosyncratic federalism doctrines that do not go to the core of Congress's regulatory power. For example, in Coyle v. Smith, 22 I U.S. 559 (I9I I), the Court famously held, based on textually unspecified principles of federalism, that Congress may not, as a condition of admitting a state into the Union, direct that state to relocate its capital. Finally, the law of federal courts includes various doctrines resting on premises of federalism that 
Third, the Court erected an elaborate (but also unevenly applied) doctrine of intergovernmental tax immunity, reasoning that federal taxation would impair the states' capacities to fulfill their (unenumerated) sovereign functions. ${ }^{83}$

After I937, these limitations broke down. The Court had, in a series of high-profile cases, relied on some of the foregoing doctrines to invalidate core elements of the New Deal. ${ }^{84}$ But, by 1937, the Court yielded to the nationalizing temper of the times. It made clear not only that intrastate activity fell within the Commerce Clause if it affected interstate commerce, but also that almost any activity, however marginal to the national economy, could have the requisite effect. ${ }^{85}$ It abandoned the notion of dual federalism as a distinct constraint on federal power. ${ }^{86}$ And it pared back intergovernmental tax immunity to

the Court has not tied directly to a textual source. See, e.g., Murdock v. Memphis, 87 U.S. (20 Wall.) 590 (I875) (adequate and independent state ground). Because I am interested solely in the methodology used by the recent cases, I will not subject these earlier opinions to scrutiny here.

83 In Collector v. Day, 78 U.S. (I I Wall.) I I 3 (I 87 I), the Court held that Congress may not impose a general tax on the salary of state court judges. Although acknowledging that "no express provision in the Constitution ... prohibits the general government from taxing the means and instrumentalities of the States," the Court held that "the exemption rests upon necessary implication, and is upheld by the great law of self-preservation; as any government, whose means employed in conducting its operations, if subject to the control of another and distinct government, can exist only at the mercy of that government." Id. at I27. Day also rested on the idea that the federal and state governments are "separate and distinct sovereignties, acting separately and independently of each other, within their respective spheres." Id. at I24. This doctrine was the mirror image of the rule, announced in McCulloch v. Maryland, I7 U.S. (4 Wheat.) 316,428 (I8I9), that states cannot tax federal instrumentalities. Over the years, the force of the intergovernmental tax immunity doctrine eroded. The tax immunity was keyed to the incidence of the tax upon traditional or usual governmental activities, and the Court did not have an easy time articulating the basis for distinguishing taxable from nontaxable functions. See Garcia v. San Antonio Metro. Transit Auth., 469 U.S. 528, 540-43 (1985) (discussing the instability and line-drawing difficulties in the intergovernmental tax immunity cases).

84 See, e.g., Carter v. Carter Coal Co., 298 U.S. 238 (I936) (invalidating the Bituminous Coal Conservation Act of 1935 on federalism grounds); United States v. Butler, 297 U.S. I (I936) (striking down on Tenth Amendment grounds a provision of the Agricultural Adjustment Act that levied taxes on agricultural processors to pay farmers for acreage reductions); Schechter Poultry, 295 U.S. at 542-5 I (holding unconstitutional central provisions of the National Industrial Recovery Act on the ground that they had only an indirect rather than direct effect upon interstate commerce).

85 See, e.g., Wickard v. Fillburn, 3I7 U.S. II I, I28 (I942) (holding that Congress can regulate the prices of wheat grown for a farmer's personal consumption on the ground that "his contribution, taken together with that of many others similarly situated, is far from trivial" in its effect upon interstate commerce); United States v. Wrightwood Dairy Co., 3 I5 U.S. I Io, I I9 (I942) (recognizing Congress's power to regulate intrastate milk production on the ground that the Commerce Clause "extends to those activities intrastate which so affect interstate commerce, or the exertion of the power of Congress over it, as to make regulation of them appropriate means to the attainment of a legitimate end, the effective execution of the granted power to regulate interstate commerce").

86 See, e.g., United States v. Darby, 3 I2 U.S. Ioo, II4 (I94I) ("It is no objection to the assertion of the power to regulate interstate commerce that its exercise is attended by the same incidents which attend the exercise of the police power of the states."); Corwin, supra note 82, at I7 ("Today 
cover only those federal taxes which discriminated against state governmental actors. ${ }^{87}$ The standard view is that, in these developments, the Court's shift reflected the reality of the increasingly integrated character of our national economy, yielded to the irresistible demand for national economic intervention in the wake of the Great Depression, and acknowledged the unstable and unprincipled line-drawing that had characterized the various areas of federalism doctrine. ${ }^{88}$ Whatever the reason, with the exception of one short-lived attempt to reinvigorate a Tenth Amendment constraint on Congress's ability to regulate states qua states ${ }^{89}$ for more than five decades after 1937 the Court gave Congress an open field for erecting a broad federal regulatory state.

As discussed, the Court's cases have recently begun to carve out a new conception of limited federal power relative to the states. To examine them fairly, one must understand the new federalism cases as reflecting three impulses. First, the Rehnquist Court made an obvious judgment that the post-I937 abandonment of federalism constraints on legislative power risked eliminating any meaningful residual role for state sovereignty in our system of government. ${ }^{\circ 0}$ Second, the Court has not been prepared to return to anything like the pre-I937 system of complementary Commerce Clause and Tenth Amendment limitations on the regulatory scope of enumerated powers. Perhaps out of

neither the State Police Power nor the concept of Federal Equilibrium is any 'ingredient of national legislative power,' whether as respects subject-matter to be governed, or the choice of objectives or of means for its exercise." (quoting 2 ANNALS OF CONG. I89I (I79I))).

87 In Graves v. New York ex rel. O'Keefe, 306 U.S. 466, 487 (I939), the Court overruled Collector. Presently, the availability of intergovernmental tax immunity turns primarily on the question of whether a federal tax discriminates against state employees or those with whom the state deals. See Davis v. Mich. Dep't of Treasury, 489 U.S. 803, 8I I (I989) ("After Graves, . . intergovernmental tax immunity barred only those taxes that were imposed directly on one sovereign by the other or that discriminated against a sovereign or those with whom it dealt.").

88 See, e.g., Larry Kramer, Understanding Federalism, 47 VAND. L. REV. I485, I497 (I994) ("As product, labor, and capital markets became nationally integrated,... [d]istinctions like 'commerce versus manufacture,' 'direct versus indirect,' or 'local versus interstate' no longer made sense in a nation where effects necessarily rippled across state lines.”); Lawrence Lessig, Translating Federalism: United States v. Lopez, I995 SUP. CT. REV. I25, I35-44 (explaining the role of economic integration in the breakdown of the Commerce Clause as a meaningful source of limitations upon congressional power).

89 See Nat'l League of Cities v. Usery, 426 U.S. 833, $85^{2}$ (I976), overruled by Garcia v. San Antonio Metro. Transit Auth., 469 U.S. 528 (1985).

90 See H. Geoffrey Moulton, Jr., The Quixotic Search for a Judicially Enforceable Federalism, 83 MiNN. L. REV. 849, 894 (I999) "'The Court's doctrinal innovations in National League of Cities, Ashcroft, New York, Lopez and Printz might best be understood as reactions t[o] the Court's perception that the federal-state balance has gotten out of whack and that Congress cannot be trusted to put things right."); Ernest Young, Making Federalism Doctrine: Fidelity, Institutional Competence, and Compensating Adjustments, 46 WM. \& MARY L. REV. I733, I757-58 (2005) ("By the I990s, with national power firmly established and state autonomy seemingly endangered, the Rehnquist Court was acting . . to rein in national authority.”). 
concern that the pre-I937 doctrine did not produce principled adjudication or that the present demand for national power has become too well entrenched to repudiate the post-I937 settlement, the modern Court's reassertion of judicially enforceable Commerce Clause limits has taken only the modest step of insisting that Acts of Congress either regulate some sort of "economic activity" or contain findings that would enable the Court to determine whether noneconomic activity "substantially affected interstate commerce, even though no such substantial effect was visible to the naked eye." 11 Third, the Court has evidently concluded that, if modern Commerce Clause doctrine threatens its minimum conception of state sovereignty, it will handle the problem by recognizing implied limitations in federal power that are

91 See United States v. Lopez, 5 I4 U.S. 549, 56I-63 (I995) (invalidating the Gun-Free School Zones Act); see also United States v. Morrison, 529 U.S. 598 (2000) (relying on Lopez to invalidate a portion of the Violence Against Women Act). As Professor Richard Fallon has written:

The Court's effort to restrict Congress's general regulatory powers occasioned embarrassment and near disaster during the economic and political crises of the I930s. Then, when the Court shifted course and authorized broad assertions of congressional power, patterns of reliance developed.... Although eager to promote federalism through modest doctrinal reform and to shape new options for the future, the Court now hesitates to take aggressive steps, threatening entrenched regulatory regimes back into territory that it previously abandoned.

Richard H. Fallon, Jr., The "Conservative" Paths of the Rehnquist Court's Federalism Decisions, 69 U. CHI. L. REV. 429, 436 (2002); see also, e.g., H. Jefferson Powell, The Oldest Question of Constitutional Law, 79 VA. L. REV. 633, 670 (1993) (arguing that the pre-New Deal approach might be unattractive to the Court because it was "marked by rapid swings between generous and pinched readings of congressional powers" and because "the social reality [is] that virtually all political groups and persuasions want broad national powers wielded on behalf of their desired objectives").

In a distinct series of prominent but controversial modern cases, the Court has further constrained federal legislative power by emphasizing that Section 5 of the Fourteenth Amendment assigns Congress power "to enforce" that amendment, not to extend or reinterpret the substantive rights recognized under the amendment. See City of Boerne v. Flores, 52 I U.S. 507, 519-20 (1997) (holding that to prevent a Section 5 statute from crossing the line from appropriate enforcement into improper substantive alteration of constitutional rights, the Court had to find "congruence and proportionality between the injury to be prevented or remedied and the means adopted to that end"); see also, e.g., Nev. Dep't of Human Res. v. Hibbs, 538 U.S. 72 I (2003) (finding the Family Medical Leave Act to be an appropriate exercise of Section 5 power under the congruence and proportionality test); Bd. of Trs. of the Univ. of Ala. v. Garrett, 53 I U.S. 356, 36574 (200I) (applying the congruence and proportionality test to conclude that Congress cannot derive authority for the Americans with Disabilities Act from Section 5); Kimel v. Fla. Bd. of Regents, 528 U.S. 62, 82-83 (2000) (applying the test to hold that Section 5 cannot justify the Age Discrimination in Employment Act). Although important, the Section 5 cases do not approximate the very substantial restrictions on the scope of federal power that characterized the pre-I937 case law. This Article does not examine these cases because they do not rest upon freestanding federalism, but rather purport to rest on a discrete constitutional text. 
traceable to some form of historically reconstructed original understanding of the appropriate federal-state balance. ${ }^{92}$

The last of these strategies is of central interest here. In three key doctrinal areas, the Court has sought to root its understanding of constitutional meaning in a conception of federalism qua federalism, drawn from the constitutional structure as a whole. First, the Court has enforced a strict federalism-based clear statement rule requiring Congress to express its intentions unmistakably if it wishes to disrupt some hypothetical state-federal balance. Second, the Court has articulated an anticommandeering doctrine by inferring from multiple clauses a general purpose of adopting a federal system and then treating that general purpose of federalism as a warrant to enforce the founders' uncodified expectations about limits on federal power. Third, the Court has relied on a similar technique to recognize broad state sovereign immunity against suit in state court, explicitly disclaiming any textually grounded source for such immunity.

To set the stage for considering (in Part III) whether the methodology underlying this line of cases can be reconciled with the process assumptions underlying the Court's modern statutory cases, this Part describes the reasoning of the new federalism cases and argues that large elements of that reasoning reflect precisely the sort of purposive approach that the Court's statutory cases reject.

\section{A. Federalism Clear Statement Rules}

The Court has adopted a cluster of clear statement rules that protect a broad value of federalism by presuming that absent a plain statement of legislative intent, Acts of Congress cannot intrude upon the usual balance of state and federal power. These cases start from the assumption that Congress may regulate the states in the way that the clear statement rule disfavors, so long as the statute does so with an exceptional degree of clarity. Although the Court has long applied such a rule in particular contexts of federal intrusion upon state pre-

92 See, e.g., Roderick M. Hills, Jr., The Political Economy of Cooperative Federalism: Why State Autonomy Makes Sense and "Dual Sovereignty" Doesn't, 96 MICH. L. REV. 8I3, 83 I (1998) (noting that the Court's anticommandeering cases "rely heavily" on "originalist history" to support their conclusions); Ernest Young, Alden v. Maine and the Jurisprudence of Structure, 4I WM. \& MARY L. REV. I60I, I620 (2000) (noting "the virtual unanimity with which the Justices have accepted the primacy of historical argument" in the new federalism cases and suggesting that such analysis ties in with "a theory of constitutional positivism" that seeks to recover the original meaning attached to the document at the time of its ratification). 
rogatives, ${ }^{93}$ Gregory v. Ashcroft ${ }^{94}$ adopted the first broad-gauged federalism canon of clear statement. The Court thus emphasized that "if Congress intends to alter the usual constitutional balance between the States and the Federal Government, it must make its intention to do so 'unmistakably clear in the language of the statute." 95 At issue was whether the federal Age Discrimination in Employment Act ${ }^{96}$ (ADEA) applied to state judges. The Missouri Constitution compelled most state judges to retire at age seventy. The ADEA imposes liability upon any "employer" who "discharge[s] any individual" at least forty years of age "because of such individual's age." 97 The Act explicitly defines "employer" to include "a State or political subdivision of a State." 98 Although the ADEA contains an explicit exemption for high-level government officials, the Court acknowledged that the exemption did not comfortably apply to judges. ${ }^{99}$ Despite the Act's apparent applicability, however, the Court found that Congress had the burden to make its intention to cover judges unmistakable:

[W]e are not looking for a plain statement that judges are excluded. We will not read the ADEA to cover state judges unless Congress has made it clear that judges are included. This does not mean that the Act must mention judges explicitly .... Rather, it must be plain to anyone reading

93 Perhaps the most commonly invoked federalism canon is the presumption against preemption of state law by a federal statute. Although the Court applies this canon inconsistently, it has unmistakably articulated a presumption "that the historic police powers of the States [are] not to be superseded by [a] Federal Act unless that was the clear and manifest purpose of Congress." Rice v. Santa Fe Elevator Corp., 33I U.S. 2 I8, 230 (I947); see also, e.g., Medtronic, Inc. v. Lohr, 5 I8 U.S. 470, 485 (I996) (reiterating that presumption); Hillsborough County v. Automated Med. Labs., Inc., 47 I U.S. 707, 7 I6 (1985) (referring to the interpretive "presumption that state and local regulation of health and safety matters can constitutionally coexist with federal regulation"). The presumption against preemption goes not merely to the question of whether to find implied preemption, but also instructs courts to construe narrowly provisions that expressly preempt state law. See Cipillone v. Liggett Group, Inc., 505 U.S. 504, 5 I8 (I992) (holding that the presumption against preemption "reinforces the appropriateness of a narrow reading"). An extensive body of scholarship has grown up around the presumption against preemption. See, e.g., Roderick M. Hills, Jr., Against Preemption: How Federalism Can Improve the National Legislative Process, 82 N.Y.U. L. REV. I (2007) (arguing that the configuration of interest groups for and against preemption makes it more likely that a presumption against preemption would provoke full and open congressional deliberation about the desirability vel non of uniform national regulation); Caleb Nelson, Preemption, 86 VA. L. REV. 225 (2000) (arguing that the original understanding of the Supremacy Clause contradicts any presumption against preemption).

94 501 U.S. 452 (I99I).

95 Id. at 460 (quoting Will v. Mich. Dep't of State Police, 49I U.S. 58, 65 (I989)) (internal quotation marks omitted).

9629 U.S.C. $\$ \S 62 \mathrm{I}-34(2006)$.

97 Id. $\$ \S 623(\mathrm{a}), 63 \mathrm{I}(\mathrm{a})$.

98 Id. $\$ 630(\mathrm{~b})(2)$.

99 The Court conceded that the only plausible exemption - for "appointee[s] on the policymaking level," id. $§ 630(f)$ - would be "an odd way for Congress to exclude judges." Gregory, 5 o I U.S. at 467. Note, moreover, that a tailored exemption for some such high government officials would not make sense unless the Act presumptively otherwise covered such officials. 
the Act that it covers judges. In the context of a statute that plainly excludes most important state public officials, "appointee on the policymaking level" is sufficiently broad that we cannot conclude that the statute plainly covers appointed state judges. Therefore, it does not. ${ }^{100}$

Although a broad scholarly debate has emerged about the underlying practice of using clear statement rules to enforce constitutional values, ${ }^{101}$ for present purposes the relevant question goes to the way the Court derived its "federalism" norm. Previously, in Garcia v. San Antonio Metropolitan Transit Authority, ${ }^{102}$ the Court had held that the Commerce Power authorizes Congress to apply federal employment laws to those who work for state government. ${ }^{103}$ Hence, no constitutional impediment precluded Congress from applying the ADEA to state hiring practices. Against this backdrop, Gregory used a clear statement rule to raise the cost of legislation that would disrupt "the

100 Gregory, 50 I U.S. at 467 (citation omitted).

101 A prominent defense of clear statement rules treats them as nondelegation canons that merely require Congress to articulate explicitly its purpose to intrude upon constitutionally favored values. Hence, they promote constitutional values without the heavy touch of judicial review. See Cass R. Sunstein, Nondelegation Canons, 67 U. CHI. L. REV. 3I5, 33I-32 (2000). A competing position views such canons as "resistance norms," raising the cost to Congress of ranging into constitutionally troublesome areas. Ernest A. Young, Constitutional Avoidance, Resistance Norms, and the Preservation of Judicial Review, 78 TEX. L. REV. I549, I552 (2000). Critics argue that the Court picks and chooses the constitutional values enforced through clear statement rules in a way that favors economic liberties and state autonomy over individual rights. See, e.g., Eskridge, supra note 7 I, at I 542-52; Bradford C. Mank, Textualism's Selective Canons of Statutory Construction: Reinvigorating Individual Liberties, Legislative Authority, and Deference to Executive Agencies, 86 KY. L.J. 527, 527 (I998). Others have argued that by requiring courts to adopt a strained or unnatural reading of a statute, clear statement rules displace congressional policymaking prerogatives at least as significantly as does judicial review. See Frederick Schauer, Ashwander Revisited, I995 Sup. CT. REV. 7 I; $c f$. JERry L. MASHAw, GreEd, ChAOS, AND Governance: Using Public Choice To ImProve Public LAW I05 (I997) (arguing that deliberate misconstruction of a statute may impinge on legislative prerogatives more severely than would outright invalidation, at least if the misconstruction was sufficiently in sync with the preferences of one of the three actors in the legislative process). Judge Posner, moreover, has argued that clear statement rules create "judge-made constitutional "penumbra[s]" that unwisely extend the document's reach. Richard Posner, Statutory Interpretation - In the Classroom and in the Courtroom, 50 U. CHI. L. REV. 800, 8I6 (I983). For purposes of considering the derivation of the "federalism" norm, my analysis in the text takes up where Judge Posner leaves off — suggesting a process-based reason why judges should decline to apply and enforce such penumbras.

102469 U.S. 528 (1985).

103 The Court had reasoned that the Constitution, in fact, adopts political rather than judicial safeguards for the preservation of state autonomy against federal power. Noting that the Constitution confers upon the states explicit means of influence over the selection of representatives, senators, and the President, the Court concluded that the resultant process safeguards sufficiently ensure against congressional abuse of the Commerce Power as applied to states qua states:

[T] The principal and basic limit on the federal commerce power is that inherent in all congressional action — the built-in restraints that our system provides through state participation in federal governmental action. The political process ensures that laws that unduly burden the States will not be promulgated. In the factual setting of these cases the internal safeguards of the political process have performed as intended.

Garcia, 469 U.S. at 556 . 
usual constitutional balance" between the state and federal sovereigns. Difficulty in identifying a usual or traditional set of core state functions had played an important role in the Court's earlier Garcia decision. ${ }^{104}$ Despite that difficulty, however, the Gregory Court thought it necessary and appropriate to find a means to enforce the background idea that "our Constitution establishes a system of dual sovereignty between the States and the Federal Government."105 Maintaining "a healthy balance of power between the States and the Federal Government," the Court emphasized, "will reduce the risk of tyranny and abuse from either front." 106 It also stressed that promoting federalism encourages innovation, experimentation, competition, and greater sensitivity to a heterogeneous society. ${ }^{107}$ Building on these broad constitutional purposes, the Court found it straightforward to require a clear legislative statement before ascribing to Congress an intention to intrude upon a state practice — selecting and retaining judges — that affects the way a state "defines itself as a sovereign." 108

104 Under pre-Garcia federalism doctrine, the Court had held that Congress could not apply an otherwise valid exercise of the Commerce Power in a way that would impair the states' ability "to structure integral operations in areas of traditional governmental functions ...." Nat'l League of Cities v. Usery, 426 U.S. 833, 852 (I976). The Court in Garcia found it unworkable to distinguish between such traditional governmental functions and other state activities that fell within the legitimate reach of federal commerce power. See Garcia, 469 U.S. at 537-47.

105 Gregory, 50I U.S. at 457.

$106 I d$. at 458 .

107 Id.

108 Id. at 460. The Court has invoked this idea of the balance of federal and state power to insist upon clear statements of legislative intent in other contexts as well. For example, the Court applied a strong version of the federalism canon in BFP v. Resolution Trust Corp., 5 I I U.S. 53 I (I994), which addressed a provision of the Bankruptcy Code allowing creditors to void certain transfers of property by insolvent debtors unless the debtor received "reasonably equivalent value" in the transaction. Id. at 533 (quoting I I U.S.C. $\S 548(\mathrm{a})(2)$ (I 988$)$ ). The precise issue was what "reasonably equivalent value" meant in the context of a foreclosure sale of the debtor's property. Rather than requiring rough market equivalence (as several courts of appeals had), the Court held that if the foreclosure followed applicable state procedures, "reasonably equivalent value" was whatever the foreclosure sale yielded. Id. at 545. Invoking the Court's federalism canon, Justice Scalia reasoned that the statutory language simply did not evince a "clear and manifest" intent, $i d$. at 544 , to "displace traditional state regulation" of foreclosure sales, $i d$. at 544-45. As Professor William Eskridge has shown, BFP reflects a strong application of the clear statement rule; if "reasonably equivalent value" is whatever the state foreclosure procedures fetch, then the provision in question has no constraining effect upon foreclosures. See Eskridge, supra note 7I, at I545. Similarly, in Will v. Michigan Department of State Police, 49I U.S. 58 (I989), the Court held that neither a state nor an officer of the state acting in his or her official capacity constituted a "person" for purposes of 42 U.S.C. $\S 1983$, which imposes liability upon any "person" who "under color of [state law]" deprives anyone of "any rights, privileges, or immunities secured by the Constitution and laws." 42 U.S.C. $\S 1983$ (2000). In so holding, the Court invoked the canon that Congress must speak with unmistakable clarity if it wishes to disturb the traditional balance of state and federal power. See Will, 49 I U.S. at 65; see also, e.g., Pennhurst State Sch. \& Hosp. v. Halderman, 45 I U.S. I, I7 (I98I) (requiring a clear statement of congressional intent to condition state receipt of federal monies on compliance with stated conditions). 
In deriving its clear statement rule, the Court did not purport to rest on any particular textual source in the Constitution. Nor did it purport to rely on any specific historical understanding of implied limits on Article I power. Rather, the Court practiced classical purposivism. Starting from the uncontroversial proposition that "[t]he Constitution created a Federal Government of limited powers,"109 the Court's analysis used (a) the fact of limited and enumerated powers to establish (b) a purpose of preserving residual state sovereignty that then (c) justified the derivation of implied limitations on what the Court assumed to be an otherwise valid exercise of the enumerated powers (application of the ADEA to state employment). In other words, the Court abstracted from the specific enumeration of powers in Article I a general purpose of "federalism" that is both broader and more potent than the enumeration from which it is derived. However sensible Gregory's particular limitation on federal interference with state judicial tenure may seem when imagining the contours of a dual sovereignty, ${ }^{110}$ the fact remains that the Court rested its authority on the abstraction of a freestanding federalism found nowhere in the text.

\section{B. Anticommandeering}

Purposivist techniques of the sort rejected in the Court's statutory cases are also evident in its two anticommandeering cases. The anticommandeering idea originated in New York $v$. United States, ${ }^{111}$ a case in which the Court held that it contradicted principles of federalism for Congress to require states to establish mechanisms for the disposal of toxic waste generated within their borders. Under the Low-Level Radioactive Waste Policy Amendments Act of $1985,{ }^{112}$ Congress stated that if any state did not provide for disposal of low-level radioactive waste within a specified time frame, that state would first face rapidly increasing surcharges for its disposal and would eventually have to take title to waste generated within its borders if the generator or owner so requested.113 Although acknowledging that the Commerce Power authorizes Congress to regulate disposal of low-level radioactive

109 Gregory, 50 I U.S. at 457; see also id. ("As every schoolchild learns, our Constitution establishes a system of dual sovereignty between the States and the Federal Government.").

110 The Court in Gregory argued that the states have the authority "to determine the qualifications of their most important government officials," $i d$. at $46_{3}$, because that authority "lies at the heart of representative government," id. (citing Bernal v. Fainter, 467 U.S. 2 I6, 22 I (I984)) (internal quotation marks omitted). The Court reserved the question whether this authority might fall within Article IV of the Constitution, pursuant to which the United States "guarantee[s] to every State in this Union a Republican Form of Government." Id. (quoting U.S. CoNST., art. IV, § 4) (internal quotation marks omitted); see also infra note 260.

111505 U.S. I44 (I992).

112 Pub. L. No. 99-240, 99 Stat. I842 (I 986) (current version at 42 U.S.C. $\$ \$ 202$ Ib-202 Ij).

113 See 42 U.S.C. $\S 202 \mathrm{Ie}(\mathrm{e})(2)$ (phased-in surcharges); $i d . \S 202 \mathrm{Ie}(\mathrm{d})(2)(\mathrm{C})$ (take-title provision). 
waste, the Court found that commandeering state political processes to effectuate federal regulatory goals invaded a sphere of state autonomy that background principles of federalism protected. ${ }^{114}$

What is crucial here, as with the Gregory clear statement canon, is that the Court pointed to no specific textual source for its conclusion. (Indeed, the Court acknowledged that the tautological wording of the Tenth Amendment imposes no independent constraint on federal power. ${ }^{115}$ ) Rather, the Court's newly derived limitation rested on the apparent purpose underlying the rejection of a proposal at the Philadelphia Convention. ${ }^{116}$ Under the Articles of Confederation, the Confederation Congress had authority to act only through the agency of state governments, and could not regulate the people directly. ${ }^{117}$ In the Philadelphia Convention, the New Jersey Plan proposed a similar system, but the "idea apparently never even progressed so far as to be debated by the delegates." 118 Instead, the Convention authorized Congress to act directly upon the populace. As the Court in New York emphasized, the ratifying conventions highlighted this choice:

Oliver Ellsworth, a member of the Connecticut delegation in Philadelphia, explained the distinction to his State's convention: "This Constitution does not attempt to coerce sovereign bodies, states, in their political capacity. ... But this legal coercion singles out the ... individual." Charles Pinckney, another delegate at the Constitutional Convention, emphasized to the South Carolina House of Representatives that in Philadelphia "the necessity of having a government which should at once operate upon the people, and not upon the states, was conceived to be indispensable by every delegation present." Rufus King, one of Massachusetts' delegates, returned home to support ratification by recalling the Commonwealth's unhappy experience under the Articles of Confederation and arguing: "Laws, to be effective, therefore, must not be laid on states, but upon individuals." At New York's convention, Hamilton (another delegate in Philadelphia) exclaimed: "But can we believe that one state will ever suffer itself to be used as an instrument of coercion? The thing is a dream; it is impossible. Then we are brought to this dilemma - either a federal standing army is to enforce the requisitions, or the federal treasury is left without supplies, and the government without support. What, sir, is the cure for this great evil? Nothing, but to enable the national laws to operate on individuals, in the same manner as those of the states do." At

\footnotetext{
114 New York, 505 U.S. at I88.

115 Id. at $\mathrm{I} 88$.

116 Id. at $\mathrm{I} 64-65$.

117 Id. at 163 .

$118 I d$. at I65. The New Jersey Plan had proposed in relevant part that "the laws of the United States ought, as far as may be consistent with the common interests of the Union, to be carried into execution by the judiciary and executive officers of the respective states, wherein the execution thereof is required." 3 RECORDS OF THE FEDERAL CONVENTION OF I787, at 6r6 (Max Farrand ed., rev. ed. 1937) [hereinafter CONVENTION RECORDS].
} 
North Carolina's convention, Samuel Spencer recognized that "all the laws of the Confederation were binding on the states in their political capacities, ... but now the thing is entirely different. The laws of Congress will be binding on individuals." 119

Based on this legislative history of the founding, the Court concluded that "even where Congress has the authority under the Constitution to pass laws requiring or prohibiting certain acts, it lacks the power directly to compel the States to require or prohibit those acts." 120

In Printz v. United States, ${ }^{121}$ a later anticommandeering opinion that elaborated on the doctrine's rationale, the Court confirmed the atextual, purposive nature of its analysis. Perhaps most important, it readily conceded that "there is no constitutional text speaking to this precise question." 122 Instead, the Court abstracted a general background value of "dual sovereignty" from specific provisions spread throughout the entire document:

It is incontestible that the Constitution established a system of "dual sovereignty." Although the States surrendered many of their powers to the new Federal Government, they retained "a residuary and inviolable sovereignty."123 This is reflected throughout the Constitution's text, including (to mention only a few examples) the prohibition on any involuntary reduction or combination of a State's territory, Art. IV, $\S 3$; the Judicial Power Clause, Art. III, $\S 2$, and the Privileges and Immunities Clause, Art. IV, $\S 2$, which speak of the "Citizens" of the States; the amendment provision, Article V, which requires the votes of three-fourths of the States to amend the Constitution; and the Guarantee Clause, Art. IV, § 4, which "presupposes the continued existence of the states and...those means and instrumentalities which are the creation of their sovereign and reserved rights." Residual state sovereignty was also implicit, of course, in the Constitution's conferral upon Congress of not all governmental powers, but only discrete, enumerated ones, Art. I, $\S 8$, which implication was rendered express by the Tenth Amendment[] . . . ${ }^{124}$

119 New York, 505 U.S. at I65-66 (quoting 2 JONATHAN Elliot, Debates ON THE FedERAL CONSTITUTION 56, I97, 233 (2d ed. I863); 4 id. at 256, I53).

$120 I d$. at $\mathrm{I} 66$.

12152 I U.S. 898 (1997). In Printz, the Court extended the New York Court's anticommandeering principle to a statute purporting to require state executive officials to implement the Brady Bill's gun registration and information check provisions. See id. at 903-04.

122 Id. at 905 . To be fair, the "precise question" was whether Congress may compel the states to enact or administer a federal regulatory program, and the text does not specify an answer one way or the other. See Bradford R. Clark, Translating Federalism: A Structural Approach, 66 Geo. WASH. L. Rev. ir6i, i I88 (I998). According to Professor Bradford Clark, the opinion, properly understood, construed the proper scope of Article I powers. Id. at I I89. The important point, for present purposes, is that Printz's reasoning addresses not whether the activity in question constituted "Commerce among the several States," but whether the purposes underlying the Constitution's adoption suggest a basis for inferring an implied limitation on such power.

123 The Federalist No. 39, at 245 (James Madison) (Clinton Rossiter ed., I96I).

124 Printz, 52 I U.S. at 9I8-I9 (emphasis added) (citations omitted). 
In addition, the Court gave authoritative weight to the purposes behind the founders' rejection of the proposal to use states affirmatively to enforce federal law. The Records of the Federal Convention $^{125}$ and the ratifying debates thus suggested that federal dependence on state enforcement during the Confederation period had produced mischiefs that the founders wished to avoid. ${ }^{126}$ In the Court's view, construing our dual sovereignty to prohibit commandeering of state enforcement mechanisms would fulfill that aim. The Court also cited an absence of any early commandeering statutes or references to such power in the framers' writings as affirmative evidence of the practice's unacceptability. ${ }^{127}$

The Court made no real attempt to tie the anticommandeering principle to any explicit clause of the Constitution, and the mere absence of early commandeering statutes might reflect many factors apart from an affirmative (but still unexpressed) social consensus against such a practice. Ultimately, the Court's analysis in both New York and Printz rests, in important part, on evidence that some founders disfavored commandeering and that they adequately expressed that purpose when they rejected a proposal to embrace such a practice, even though they took no affirmative steps to reduce that purpose to a textual proscription.

\section{Sovereign Immunity}

In an area long characterized by purposive interpretation of the constitutional text, the Court broke new ground in Alden v. Maine ${ }^{128}$ by recognizing a broad form of sovereign immunity that did not even pretend to originate in the text of the Eleventh Amendment, the primary source upon which the Court had traditionally relied in deriving state sovereign immunity from suit in federal courts. ${ }^{129}$ To be sure, the Court's Eleventh Amendment jurisprudence itself rests on a strongly purposive interpretation of the amendment. Although that amend-

125 CONVENTION RECORDS, supra note i I8.

126 See Printz, 52 I U.S. at 9I9 (“The Framers' experience under the Articles of Confederation had persuaded them that using the States as the instruments of federal governance was both ineffectual and provocative of federal-state conflict.").

127 See id. at 909-18. A large body of excellent scholarship has addressed the textual, structural, and historical considerations surrounding the commandeering question. See, e.g., Evan H. Caminker, State Sovereignty and Subordinacy: May Congress Commandeer State Officers To Implement Federal Law?, 95 ColuM. L. REV. Iоo ( I995); Vicki C. Jackson, Federalism and the Uses and Limits of Law: Printz and Principle?, I I I HARV. L. REV. 2 I80 (I998); Saikrishna Bangalore Prakash, Field Office Federalism, 79 VA. L. REV. I957 (I994).

128527 U.S. 706 (I999).

129 The Eleventh Amendment provides that "[t]he Judicial power of the United States shall not be construed to extend to any suit in law or equity, commenced or prosecuted against one of the United States by Citizens of another State, or by Citizens or Subjects of any Foreign State." U.S. CONST. amend. XI. 
ment almost surgically withdraws from Article III categories of jurisdiction involving any suit against a state "by Citizens of another State, or by Citizens or Subjects of any Foreign State," the Court has long construed it to provide sovereign immunity against federal court actions by a state's own citizens. ${ }^{130}$ The Court's reason for construing the amendment broadly rests upon its relationship to the Jay Court's decision in Chisholm v. Georgia, ${ }^{131}$ whose seriatim opinions had held (over one dissent) that background principles of state sovereign immunity did not survive Article III's adoption and, in particular, that federal courts could entertain a common law action for debt brought against a state by a citizen of another state under Article III's CitizenState Diversity Clause. ${ }^{132}$ Although in reversing that decision the amendment's text only singled out a precise class of diversity cases closely related to the particular case in Chisholm, the famous nineteenth-century decision in Hans v. Louisiana ${ }^{133}$ held that the amendment, in fact, had the broader purpose to reverse Chisholm's reasoning wholesale and to restore an antecedent (and, in its view, correct) understanding that states possessed immunity from suit without their consent. ${ }^{134}$ If Chisholm established that state sovereign immunity did

130 See, e.g., Seminole Tribe v. Florida, 5 I 7 U.S. 44, 57-73 (I996); Hans v. Louisiana, I34 U.S. I, I8-I9 (I890).

1312 U.S. (2 Dall.) 4 I 9 (I793).

132 See, e.g., id. at 450 (opinion of Blair, J.) (explaining that the judicial power is "expressly extended" to suits between a state and citizens of another state); $i d$. at 466 (opinion of Wilson, J.) ("[C]ould this strict and appropriated language [of the Citizen-State Diversity Clause] describe, with more precise accuracy, the cause now depending before the tribunal?"); id. at 467 (opinion of Cushing, J.) ("The case ... seems clearly to fall within the letter of the Constitution."); id. at 477 (opinion of Jay, C.J.) (emphasizing that Chisholm's suit "clearly falls not only within the spirit, but the very words of the Constitution"); see also U.S. CONST. art. III, § 2 (granting jurisdiction over "Controversies . . . between a State and Citizens of another State").

133 I 34 U.S. I (I890).

134 Referring to Justice Iredell's dissent in Chisholm, the Hans Court thus explained: [A]t the first meeting of Congress [after Chisholm], the Eleventh Amendment to the Constitution was almost unanimously proposed, and was in due course adopted by the legislatures of the States. This amendment, expressing the will of the ultimate sovereignty of the whole country, superior to all legislatures and all courts, actually reversed the decision of the Supreme Court. It did not in terms prohibit suits by individuals against the states, but declared the Constitution should not be construed to import any power to authorize the bringing of such suits. ...

This view of the force and meaning of the amendment is important. It shows that, on this question of the suability of the States by individuals, the highest authority of this country was in accord rather with the minority than with the majority of the court in the decision of the case of Chisholm v. Georgia, and this fact lends additional interest to the able opinion of Mr. Justice Iredell on that occasion. The other justices were more swayed by a close observance of the letter of the Constitution ... . Justice Iredell, on the contrary, contended that it was not the intention to create new and unheard of remedies, by subjecting sovereign States to actions at the suit of individuals, (which he conclusively showed was never done before,) but only, by proper legislation, to invest the 
not survive the adoption of Article III, the Hans Court held that the Eleventh Amendment - despite its narrower wording — was adopted to establish just the opposite. ${ }^{135}$

Whatever the merits or demerits of Hans, ${ }^{136}$ the interesting point, for the present analysis, is that the Rehnquist Court abandoned any pretense of resting state sovereign immunity on a particular constitutional text, such as the Eleventh Amendment. While Hans and its progeny had invoked purpose to stretch the amendment's reach, its text - limited, as it was, to federal judicial power - could not plausibly stretch far enough to justify state sovereign immunity from suit in state court. Hence, in Alden v. Maine, the Court drew the bold conclusion that sovereign immunity "neither derives from, nor is limited by, the terms of the Eleventh Amendment." ${ }^{137}$ Instead, the Court reasoned:

Various textual provisions of the Constitution [- such as Art. III, § 2; Art.

IV, §§ 2-4; and Art. V - ] assume the States' continued existence and active participation in the fundamental processes of governance. The limited and enumerated powers granted to the Legislative, Executive, and Judicial Branches of the National Government, moreover, underscore the vital role reserved to the States by the constitutional design [as, for example, under] Art. I, § 8; Art. II, §§ $2-3$; Art. III, § 2. ${ }^{138}$

The Court thus inferred that the constitutional structure "reserves to [the states] a substantial portion of the Nation's primary sovereignty, together with the dignity and essential attributes inhering in that status," and that the states are more than "mere provinces or political corporations, ... retain[ing] the dignity, though not the full authority, of sovereignty." 139

Having used that general background constitutional purpose to open the door, the Court in Alden found it rather straightforward to take the next step and attribute to the states a constitutionally pro-

federal courts with jurisdiction to hear and determine controversies and cases, between the parties designated, that were properly susceptible of litigation in courts.

Id. at I I-I 2 .

135 Id. at I5. Thus, whatever disagreement had marked the question of immunity when the Court rendered its decision in Chisholm, "the people of the United States in their sovereign capacity subsequently decided" that the views of commentators like Hamilton and Iredell "were clearly right." Id. at 14 .

136 In previous writing, I have argued that Hans does not represent a defensible reading of either the Eleventh Amendment or Article III. John F. Manning, The Eleventh Amendment and the Reading of Precise Constitutional Texts, I I3 YALE L.J. I663 (2004) (arguing that even if Chisholm had been wrongly decided, the adoption of the precise text of the Eleventh Amendment struck a balance that impliedly negated any background immunity that otherwise might have survived the Constitution's adoption).

137527 U.S. 706, 7 I 3 (I999).

138 Id. (citing Printz v. United States, 52 I U.S. 898, 9 I 9 (I997)).

139 Id. at 7 I $4-15$. 
tected immunity from suit that survived entry into the Union. Blackstone's Commentaries - the treatise of choice of the founding generation - had made plain that the sovereign (that is, the Crown) had immunity from suit without his consent. ${ }^{140}$ All of the states had embraced such sovereign immunity at the time of the ratification. ${ }^{141}$ And the ratification debates provided assurances from worthies such as Hamilton, Madison, and Marshall that the adoption of the Constitution - in particular, the clause of Article III supplying federal jurisdiction over suits between a "State and citizens of another State" would not alter that background immunity. ${ }^{142}$ At least two states (New York and Rhode Island) formally declared in the ratification process that the Constitution did not affect state sovereign immunity. ${ }^{143}$

While none of this material mentioned the states' immunity from suit in their own courts, the Court inferred that such immunity was "so well established that no one conceived it would be altered by the new Constitution."144 Hence, the "silence" was "most instructive."145 Moreover, if Hans had correctly recognized state sovereign immunity from suit in federal court, the states' immunity from suit in state court followed a fortiori because recognizing "congressional power to authorize private suits against nonconsenting States in their own courts would be even more offensive to state sovereignty than a power to authorize the suits in a federal forum."146 Doing so would "denigrate[] the separate sovereignty of the States." 147 Finally, the Court noted that federal statutes purporting to authorize suits against states in state court were simply "not enacted by early Congresses" and, indeed, "are all but absent from our historical experience." 148

As compared with the cases in the other two areas, Alden comes closest to supplementing its general reliance on "federalism" with the invocation of a specific antecedent historical tradition that might have framed the founders' understanding of federal power, even if they did not reduce that understanding to words. The fact that the Crown possessed sovereign immunity when the states were colonies - and, more important, that the states retained meaningful sovereign immunity

\footnotetext{
140 Id. at 7 I 5 (quoting I William Blackstone, Commentaries $*_{234-35}$ ).

141 Id. at 7 I5-I6.

142 Id. at 7 16-18.

143 Id. at 7I8-I9. As with the Hans Court before it, the Alden Court similarly concluded that the Eleventh Amendment did not seek to change, but rather "to restore the original constitutional design." Id. at 722 .

144 Id. at $74 \mathrm{I}$.

145 Id.

146 Id. at 749

147 Id.

148 Id. at 744
} 
prior to the Constitution's adoption - cannot be discounted. Even so, a preconstitutional tradition of that sort could not resolve very much on its own, because neither the Crown's experience nor that of the states prior to $\mathrm{I} 787$ involved assertions of immunity in the context of a compound sovereignty in which one sovereign yields power over certain subject matters to another, whose laws are deemed to be supreme within that sphere. ${ }^{149}$ Nor does one get much resolution from the absence of early federal legislation imposing liability on states in state courts. For all that we know, that omission may have reflected a more limited general conception of the scope of the Commerce Power or even of the appropriate role of the federal government, rather than a specific judgment about the amenability of states to suit.

Ultimately, Alden still places material reliance on the atextual, purposive technique that characterized Gregory and the anticommandeering cases. ${ }^{150}$ No clause of the Constitution supplied the source of this broad immunity from suit. The Court generalized the assurances of continued state immunity made by Hamilton, Madison, and Marshall in the ratifying debates, even though those assurances pertained to common law actions brought under the Citizen-State Diversity Clause of Article III rather than federal question actions in state court. Finally, and most important for the present analysis, the Court invoked the overall tenor of the many constitutional clauses that presume the "continued existence" and "vital role" of the states. In particular, it inferred a generalized purpose that states retain the "dignity" of sovereigns. And it found that a sovereign possessed of such dignity should be immune from suit. As the Alden Court itself stated: "Although the Constitution grants broad powers to Congress, our federalism requires that Congress treat the States in a manner consistent with their status as residuary sovereigns and joint participants in the governance of the Nation." 151

149 See infra pp. 2059-60.

150 For a similar account of the reasoning in Alden and other important sovereign immunity cases, see Evan H. Caminker, State Immunity Waivers for Suits by the United States, 98 MICH. L. REV. 92 (I999):

To be sure, the Court has not relied on traditional indicia of an actual historical intent such as constitutional text or the Framers' discussions during the framing or ratification periods. Instead, the Court has envisioned a hypothetical negotiation during the Framing among the United States and several states, and invoked both conceptual and pragmatic concerns to discern the most plausible combination of sovereign immunity retention and waiver given the background principles, historical conditions, and purposes of union. This approach to discerning the Framers' original understanding might aptly be characterized as "reconstructionalist" in nature, since it essentially reconstructs the most plausible agreement rather than interprets conventional historical indicia thereof.

Id. at I I $2-\mathrm{I} 3$ (footnote omitted).

151 Alden, 527 U.S. at 748. 


\section{CONSTItUtional COMPROMISE AND "OUR FEDERALISM"}

Because the new federalism cases abstract from many (relatively specific) structural clauses in the Constitution to a more general background purpose to adopt a judicially enforceable system of federalism, these cases present at least a prima facie inconsistency with the process assumptions underlying the previously discussed statutory cases. Of course, such apparent inconsistency should trouble us only if the assumptions governing the statutory cases apply to the constitutional context. Many believe that they do not. ${ }^{152}$

Most fundamentally, it is sometimes said that constitutional interpreters should not permit themselves to be governed by the "dead hand of the past." ${ }^{153}$ That contention - which does not cut obviously between a purposive and a more text-based approach ${ }^{154}$ — would seem to deny the adopted text all authoritative status. Rather than start from that question of first principle about constitutionalism, however, the analysis here proceeds from the conventional, even if not universally shared, premise that the written Constitution has binding force in our system of government. ${ }^{155}$ It further assumes that the task

152 For a summary of that intellectual tradition, see Manning, supra note I36, at I695-I70I. For a recent article arguing that the Constitution should be interpreted differently from a statute, see Kevin M. Stack, The Divergence of Constitutional and Statutory Interpretation, 75 U. CoLO. L. REV. I (2004).

153 Richard A. Posner, The Problems of Jurisprudence i37-38 (I990) ("Everyone who voted for the Constitution is long dead, and to be ruled by the dead hand of the past is not self-government in any clear sense."); see also, e.g., Paul Brest, The Misconceived Quest for the Original Understanding, 60 B.U. L. REV. 204, 225 (I980) (noting that our present society "did not adopt the Constitution, and those who did are dead and gone"); David A. Strauss, Common Law Constitutional Interpretation, 63 U. CHI. L. REV. 877, 880 (I996) ("Following a written constitution means accepting the judgments of people who lived centuries ago in a society that was very different from ours.").

154 First, it is not clear that the dead hand problem differentiates constitutional from statutory interpretation. Unless there is a principled metric for identifying at what age an enacted text loses its claim to our allegiance, the dead hand problem applies to the work product of all expired lawmaking bodies. Compare Frank H. Easterbrook, Textualism and the Dead Hand, 66 GEO. WASH. L. REV. I I I9, I I20 (I998) ("Decisions of yesterday's legislatures (and the Io4th Congress is as 'dead' for this purpose as the 5oth or the Ioth) are enforced not only because the Constitution does not treat laws as radioactive (there is no legal half-life) but also because affirming the force of old laws is essential if sitting legislatures are to enjoy the power to make new ones."), with Richard A. Primus, When Should Original Meanings Matter?, I07 MICH. L. REV. I65 (2008) (arguing that enactments should have greater authority during the lifetimes of their enactors and diminishing authority thereafter). Second, even if it is somehow undemocratic to be ruled by a long-dead generation, it is not clear why our society should be governed by that generation's purposes any more than by their detailed bargains. Indeed, where the Court is dealing with constitutional limitations on Congress's power (as in the new federalism cases), relying on purpose to expand the scope of such limitations, in fact, enhances rather than reduces the authority of the dead hand.

155 See, e.g., John Hart Ely, Democracy and Distrust: A Theory of Judicial ReVIEW I-9 (1980); Michael W. McConnell, Textualism and the Dead Hand of the Past, 66 GEO. 
of interpretation generally is to try, where possible, to recover or reconstruct a historically situated understanding of the document adopted pursuant to Articles V and VII. That approach, which welds interpretation to the authority of the constitutionmaking process, ${ }^{156}$ represents the Court's typical methodology in cases of first impression, ${ }^{157}$ including (as noted) in its new federalism cases. ${ }^{158}$ This interpretivist tradition supplies the frame of reference for the analysis that follows.

Wash. L. Rev. iा27, II29 (I998); Henry P. Monaghan, Our Perfect Constitution, 56 N.Y.U. L. REV. $353,383-87$ (I $98 \mathrm{I})$.

156 Professor Joseph Raz has thus written that "the notion of legislation imports the idea of entrusting power over the law into the hands of a person or an institution, and this imports entrusting voluntary control over the development of the law, or an aspect of it, into the hands of the legislator." Joseph Raz, Intention in Interpretation, in THE AUTONOMY OF LAW: EsSAYS ON Legal Positivism 249, 265-66 (Robert P. George ed., 1996). If interpreters assume that the meaning of legislation does not depend on what its adopters understood it to mean, then, Raz asks:

[W] hy would it matter who the members of the legislature are, whether they are democratically elected or not, whether they represent different regions of the country, or classes in the population, whether they are adults or children, sane or insane? Since the law they will end by making does not represent their intentions, the fact that their intentions are foolish or wise, partial or impartial, self-serving or public spirited, makes no difference.

Id. at 258 .

157 See, e.g., Utah v. Evans, 536 U.S. 452, 474-75 (2002) (Breyer, J.) (relying on the "text" of the Census Clause and the "history of the constitutional phrase" "actual Enumeration" to determine the validity of current Census Bureau practices); U.S. Term Limits v. Thornton, 5 I 4 U.S. 779, 827 (I995) ("[T]he available historical and textual evidence, read in light of the basic principles of democracy underlying the Constitution and recognized by this Court . . ., reveal the Framers' intent that neither Congress nor the States should possess the power to supplement the exclusive qualifications set forth in the text of the Constitution.”); Nixon v. United States, 506 U.S. 224, 233 (I993) ("The history and contemporary understanding of the impeachment provisions support our reading of the constitutional language."); Browning-Ferris Indus., Inc. v. Kelco Disposal, Inc., 492 U.S. 257, 275-76 (1989) ("We shall not ignore the language of the Excessive Fines Clause, or its history, or the theory on which it is based, in order to apply it to punitive damages."); Lynch v. Donnelly, 465 U.S. 668, 673 (I984) ("The Court's interpretation of the Establishment Clause has comported with what history reveals was the contemporaneous understanding of its guarantees."); INS v. Chadha, 462 U.S. 919, 959 (1983) (construing Article I, Section 7's bicameralism and presentment requirement in light of "the records of the [Philadelphia] Convention, contemporaneous writings and debates"); Ingraham v. Wright, 430 U.S. 65 I, 670 n.39 (1977) ("The applicability of the Eighth Amendment always has turned on its original meaning, as demonstrated by its historical derivation."); United States v. Classic, 3 I3 U.S. 299, 3 I 7-I 8 (I94I) "“To decide it we turn to the words of the Constitution read in their historical setting as revealing the purpose of its framers, and in search for admissible meanings of its words which, in the circumstances of their application, will effectuate those purposes."); South Carolina v. United States, I99 U.S. 437, 450 (I905) ("To determine the extent of the grants of power we must, therefore, place ourselves in the position of the men who framed and adopted the Constitution, and inquire what they must have understood to be the meaning and scope of those grants."); Rhode Island v. Massachusetts, 37 U.S. (I 2 Pet.) 657 , 72 I (1838) (concluding that the meaning of the Constitution "must necessarily depend on the words of the constitution [and] the meaning and intention of the convention which framed and proposed it for adoption and ratification to the conventions ... . in the several states").

158 See supra Part II, pp. 2020-36. 
Even within this tradition, however, proponents of the "living Constitution" ideal maintain that whatever method one uses for reading statutes, constitutional purposivism offers a superior way to achieve fidelity to the constitutional text, given the salient difference between the two types of instruments. ${ }^{159}$ Because the Constitution adopts a highly complex governmental structure meant to endure through the ages, many believe that the document should be read as a broad charter of government, rather than a detailed code. ${ }^{160}$ Treating it as such, moreover, is said to lend important flexibility to a document that, by virtue of Article V's strict requirements, is surpassingly hard to amend. ${ }^{161}$

This one-size-fits-all theory of the constitutional text, however, disregards an important reality of the constitutionmaking process - one that is similar, in material respects, to the features of the legislative process emphasized by the Court's modern cases. It is doubtless true

159 See Manning, supra note I36, at I698-I70 (describing the "living Constitution" tradition).

160 See, e.g., Missouri v. Holland, $25^{2}$ U.S. 4I6, 433 (I920) ("[W] that also are a constituent act, like the Constitution of the United States, we must realize that they have called into life a being the development of which could not have been foreseen completely by the most gifted of its begetters."); The Legal Tender Case, I Io U.S. 42 I, 439 (I884) ("A constitution, establishing a frame of government, declaring fundamental principles, and creating a national sovereignty, and intended to endure for ages, and to be adapted to the various crises of human affairs, is not to be interpreted with the strictness of a private contract."). For a variant of this view, see ANTONIN SCALIA, Common-Law Courts in a Civil-Law System: The Role of United States Federal Courts in Interpreting the Constitution and Laws, in A MATTER OF INTERPRETATiOn: FEDERAL COURTS AND THE LAW 3, 37 (Amy Gutmann ed., I997), which observes that "[i]n textual interpretation, context is everything, and the context of the Constitution tells us not to expect nit-picking detail, and to give words and phrases an expansive rather than narrow interpretation - though not an interpretation that the language will not bear."

This impulse, of course, is reflected in Chief Justice Marshall's famous aphorism: "[W]e must never forget that it is a constitution we are expounding." McCulloch v. Maryland, I 7 U.S. (4 Wheat.) 316, 407 (I8I9). Chief Justice Marshall added that:

A constitution, to contain an accurate detail of all the subdivisions of which its great powers will admit, and of all the means by which they may be carried into execution, would partake of the prolixity of a legal code, and could scarcely be embraced by the human mind. ... Its nature, therefore, requires, that only its great outlines should be marked, its important objects designated, and the minor ingredients which compose those objects be deduced from the nature of the objects themselves.

Id. Chief Justice Marshall's dictum, which was uttered in the context of broadly construing congressional authority to adapt to new circumstances under the Necessary and Proper Clause, does not suggest that judges should ignore differences in the level of generality at which disparate parts of the Constitution are framed.

161 See Adam M. Samaha, Dead Hand Arguments and Constitutional Interpretation, Io8 Colum. L. REV. 606, 6I9, 624 (2008) (emphasizing that "Article V's stringency is a potential explanation for creative judicial 'interpretation' of the text in a pinch"); Terrance Sandalow, Constitutional Interpretation, 79 MICH. L. REV. I033, IO46 (I98I) ("Reference to the 'important objects' of the framers rather than their specific intentions is, no doubt, a necessity if the evolving needs of the nation are to be served. The amendment process established by [A]rticle $\mathrm{V}$ simply will not sustain the entire burden of adaptation that must be borne if the Constitution is to remain a vital instrument of government."). 
that, especially in relation to the typical statute, much of the Constitution does speak in majestic generalities, thereby leaving interpreters with greater flexibility in the document's implementation over time. But that circumstance is a consequence of choices made by its drafters - perhaps of necessity - in framing the document. More importantly, it does not describe the entire document. Rather, the Constitution is framed at many different levels of generality. ${ }^{162}$ Like any lawmaker, those who frame a constitution must bargain about means as well as ends, including the tradeoff between definiteness and flexibility. If interpreters treat all provisions, no matter how precise, as broad statements of principle (or vice versa), they disregard an important element of the lawmaker's choice - whether the end product is a statute or a constitution.

From this starting point, the content of the original Constitution, as well as the circumstances surrounding its adoption, confirm the problematic nature of the Court's abstracting a freestanding federalism norm from the constitutional structure as a whole. First, no less than is true in the case of modern statutes, the original Constitution in fact reflects the end result of hard-fought compromise. Second, the document defines "federalism" only through its adoption of a number of particular measures that collectively reflect the background aim of establishing a federal system. Treating that background aim as a freestanding legal norm devalues the choice to bargain over, settle upon, and present to the ratifying conventions a cluster of relatively, even if imperfectly, specified means to achieve that aim. Third, enforcing the value of federalism in the abstract runs afoul of the notion that enacted laws have multiple, imperfectly aligned purposes. The Constitution seeks to embrace federalism but also to provide a more effective national government, and decisions about where one impulse begins and the other ends cannot be made in the abstract, without reference to the particular clauses that purport to draw the lines between those two spheres.

\section{A. Constitutional Compromise}

The analysis here starts from the premise that the Constitution reflects the fruits of compromise and that the Court should interpret it accordingly, just as recent jurisprudence has done with statutes. I come to this conclusion for three reasons. First, all "enacted" laws no matter how public-spirited or well supported by consensus - necessarily entail some degree of bargaining and compromise. That presupposition applies no less to a constitution framed by statesmen and -women than it does to a tax bill negotiated in back rooms by lobby- 
ists. Second, the Records of the Federal Convention unmistakably establish that the Constitution's structural provisions in fact represent the fruits of compromise. Third, whenever a lawmaking process consciously gives carefully designated stakeholders the right to block change, minimal respect for that process requires interpreters to recognize that the power to block lawmaking necessarily includes the power to condition assent on the adoption of laws that go so far and no farther. If the Court subscribes to this assumption in the context of statutemaking, ${ }^{163}$ the process for constitutionmaking would seem to demand similar respect. Each of these points merits brief elaboration.

First, all law reflects compromise of some sort. In recent years, many have conflated the presence of compromise with the idea that legislation sometimes reflects the influence of concentrated interest groups that purchase favorable laws through campaign contributions, the implicit promise of future employment for legislators and staff, and various other perquisites dangled before legislative actors. ${ }^{164}$ That view, of course, confines the concerns emanating from legislation-ascompromise to cases in which interest group influence is salient. On that account, if one believes that legislators act from motivations other than responsiveness to interest groups, then the practice of designing rules of construction to be sensitive to legislative bargains would have less to commend it. ${ }^{165}$ Or, at least, one might try to distinguish for interpretive purposes between legislation that results from interest-group bargaining and that which is motivated by the public interest and thus reflects some rational consensus about the public good. ${ }^{166}$ If one starts from such a demarcation, then perhaps constitutionmaking should presumptively sit on the side of public-interest legislation - to be treated as something crafted by statesmen and -women for the ages rather than as a set of deals struck by self-interested interest groups. ${ }^{167}$

163 See supra section II.B, pp. 2029-32.

164 See, e.g., William M. Landes \& Richard A. Posner, The Independent Judiciary in an Interest-Group Perspective, I8 J.L. \& ECON. 875, 877 (I975) (suggesting that interest groups purchase legislation through "campaign contributions, votes, implicit promises of future favors, and sometimes outright bribes"); George J. Stigler, The Theory of Economic Regulation, 2 BELL J. ECON. \& MGMT. SCI. 3 (I97I) (articulating an economic theory of legislation).

165 For an excellent summary of empirical and conceptual challenges to the interest-group theory of legislation, see DANIEL A. FARBER \& Philip P. Frickey, LAW AND PUBlic Choice: A CRITICAL INTRODUCTION I 2-37 (I99I).

166 For two prominent examples of articles that draw such a distinction, see Easterbrook, supra note 22, at 540-42; and Jonathan R. Macey, Promoting Public-Regarding Legislation Through Statutory Interpretation: An Interest Group Model, 86 COLUM. L. REV. 223, 228-29 (I986).

167 Professor Jon Elster argues at least "some of the actors" in the Philadelphia Convention "were genuinely moved by impartial considerations." Jon Elster, Arguing and Bargaining in Two Constituent Assemblies, 2 U. PA. J. Const. L. 345, 349 (2000). He adds that "even the actors whose concerns were purely self-interested may have been forced or induced to substitute the language of impartial argument for the language of self-interest" and that this "substitution mattered for the outcomes." Id. 
Although some believe that the original Constitution reflects the product of self-interested interest group activity, ${ }^{168}$ one need not embrace that view in order to establish that the document was the product of compromise. Legislation and constitutionmaking require compromise, whether or not the hand of interest groups is evident. ${ }^{169}$ I thus agree with Professor Jeremy Waldron that one should routinely expect to find legislative compromise simply because legislation is "the product of a multimember assembly, comprising a large number of persons of quite radically differing aims, interests, and backgrounds." 170 However simple the law and however broad the consensus that a proposed policy reflects the public interest, its framers must draw lines of inclusion and exclusion. Lawmakers must decide the law's domain: how big a problem to tackle. They must also decide how to address the problem thus defined, including whether to opt for the certainty but inflexibility of precise rules or the adaptability but unpredictability of more general standards. They must decide whether to specify exceptions or defenses and, if so, how many and what kind to allow. They must resolve (or decide not to resolve) what enforcement or remedial mechanisms should implement the law. Each of these measures, in some sense, determines how far the lawmaker is willing to go in pursuit of a goal - what price he or she is willing to pay to achieve it. Even if there is broad consensus about the basic goal of a law, there may be disagreement about how that goal should

168 Respected studies of course purport to show that the framers' proposals reflected their own or their constituents' economic interests. See, e.g., Charles A. BEARd, AN ECONOMIC INTERPRETATION OF THE CONSTItUTION OF THE United StATES (I9I3) (arguing that the framers designed the document to promote their self-interest); Robert A. McGuire, Constitution Making: A Rational Choice Model of the Federal Convention of I787, 32 AM. J. POL. SCI. 483 (I988) (arguing that the delegates' voting patterns at the Philadelphia Convention are best explained by the economic interests of their constituencies). And prominent historians of the founding have sought to demonstrate that most of the major political factions operating in the several states enjoyed meaningful representation in the Convention. See, e.g., ForRest MCDONALD, We the People: The Economic Origins of the Constitution 37 (i958) ("Politically, thirty-one of the thirty-four major factions in twelve states were represented by the delegates. . . Together, ... the delegations constituted an almost complete cross-section of the geographical areas and shades of political opinion existing in the United States in I787."); CLINTON Rossiter, I787: THE GRAND CONVENTION I40 (I966) ("[I]t is possible to identify roughly thirty stable factions... in state politics in 1787 , of which all but a half-dozen were represented in the Convention.").

The economic or interest-group theory of the Convention has not gone unchallenged. See Robert E. Brown, Charles Beard ANd the Constitution: A Critical Analysis OF "AN ECONOMIC INTERPRETATION OF THE CONSTITUTION" (I956); CHARLES WARREN, The MAKING OF THE CONSTITUTION (I929). It is unnecessary here to adjudicate the validity of Professor Charles Beard's thesis, for (as explained in the text) my contention about the compromise nature of the Constitution does not depend on the correctness of his view.

169 I have so argued in greater detail in earlier writing. See, e.g., Manning, supra note I36, at I 7 I3-I4 (discussing the role of compromise in ordinary lawmaking).

170 JEREMY WALDRON, LAW AND DISAGREEMENT I25 (I999). 
be defined or the means by which it should be pursued. Accordingly, whatever the stakes, the "specific provisions" of almost any law of even moderate complexity will reflect "the result of compromise and line-item voting." ${ }^{171}$ Even a high-minded constitution thus entails compromise.

Second, even a brief examination of the Philadelphia Convention confirms that the constitutional text in fact reflects hard-fought compromise among representatives that the several states sent to hammer out a proposal to fix the Articles of Confederation. ${ }^{172}$ Early in the Convention, George Mason nicely summarized the problem when he stated: "We all agree in the necessity of new regulations; but we differ widely in our opinions of what are the safest and most effectual." 173 Or, as one commentator put it, "Madison and his colleagues knew that, even though the broad principles of republican government were widely accepted within the Convention, they faced many dangerous battles and confrontations over these potentially divisive 'particulars." 174 The end result, as Max Farrand aptly wrote, was a "bundle of compromises." 175

The specific evidence of disagreement and compromise at Philadelphia is too familiar to require extensive recitation. If line-item voting is an indication of bargaining, the fact that the assembled state delegates took an estimated 5000 votes on the contents of the document tells the whole story. ${ }^{176}$ In some of the most celebrated examples, disagreement and debate obviously characterized the decisions: these include the composition of, and manner of selecting, the executive, ${ }^{177}$ the

171 Id.

172 This view is certainly held by the textualist judges most responsible for laying the groundwork for the statutory cases. See, e.g., Frank H. Easterbrook, Abstraction and Authority, 59 U. CHI. L. REV. 349, 366 (I992) ("The Constitution is a series of compromises . . . Prudence rather than unifying principle shaped the initial document and all of its amendments."); Antonin Scalia, Originalism: The Lesser Evil, 57 U. CIN. L. REV. 849, 86 I (I989) (describing the Constitution as an imperfect "political compromise"). Some prominent nontextualists also subscribe to that position. See, e.g., Monaghan, supra note I55, at 392 ("Like important statutes, the constitution emerged as a result of compromises struck after hard bargaining."). For an excellent discussion of the strategic considerations that go into the bargaining process in a constituent assembly, see Elster, supra note 167 , at 392-4I8 (examining, inter alia, the logrolling and bargaining strategies used by the delegates to the Philadelphia Convention).

173 I CONVENTION RECORDS, supra note i 8, at i6 I.

174 Calvin C. Jillson, Constitution Making: Conflict and Consensus in The FEDERAL CONVENTION OF I 787 , at 22 (I988).

175 MAX FARRAnd, The Framing of the Constitution of THE United States 20 I (I9I3) (internal quotation marks omitted).

176 See Elster, supra note 167 , at 363.

177 Among other things, delegates debated the executive's term of office and eligibility for more than one term; whether to have a unitary or plural executive; whether the executive should be selected by the legislature or the people; and whether the executive should merely execute the laws passed by the legislature or have other powers as well. See JAMES MADISON, Notes OF Debates in the Federal Convention of i787, at 45-50 (Adrienne Koch ed., I966). As 
method of appointing executive officers and judges, ${ }^{178}$ the locus of the veto power, ${ }^{179}$ the extent of federal judicial power and of congressional discretion to establish lower federal courts, ${ }^{180}$ and of course equal representation of states in the Senate. ${ }^{181}$ It is thus hard to deny that the

Farrand puts it, during the course of the Convention, the president evolved "[f]rom an official designed to be ... a dependent of the legislature ... into an independent figure of importance." FARRAND, supra note I75, at I6I. After considerable disagreement within the Convention about the manner of selecting a president, Farrand notes that at the end of August, the Convention sent all unfinished business to "a committee of one from each state." Id. at I64. From that committee emerged the plan for the Electoral College, with electors to be selected as each state directed. Id. To underscore how interrelated the various elements of the plan were, the same committee, having come up with what they believed was a satisfactory manner of selecting the president, recommended a host of powers - including what is now the authority conferred upon that officer by the Treaty Power and the Appointments Clause. See id. at 165.

178 See FARRAND, supra note I75, at I I9 ("After the executive, the next most difficult subject was that of the judiciary, and here also the method of selection was now the chief point in dispute."). Farrand describes a decisive part of the deliberation:

Madison, Wilson, and Gorham strenuously opposed the method previously agreed upon, that is, of a choice by the second branch of the legislature. They proposed an appointment by the executive, and when that was defeated they moved for an appointment by the executive with the "advice and consent of the second branch." This was lost on a tie vote. Since obtaining equal representation in the upper house, the small states were more than ever in favor of retaining the appointment by that body, and they finally succeeded in doing so but only by the narrow margin of this tie vote.

Id. Despite this tie vote, the Convention later voted unanimously to vest appointment power in the President with the advice and consent of the Senate. Id. at I 7 I.

179 The Philadelphia Convention rejected a proposed Council of Revision, which would have given the judiciary a share in the veto power. See I CONVENTION ReCORDS, supra note i i , at 2I. Despite persistent efforts by powerful members of the Convention (including Madison and Wilson), the Convention repeatedly voted to reject any judicial role in legislation and to vest the veto power exclusively in the executive. See id. at I04, I40; 2 CONVENTION ReCORDS, supra note II 8 , at 80, 298; see also WARREN, supra note I68, at 332-35, 338 (discussing the rejection of the Council of Revision).

180 For a discussion of the so-called Madisonian Compromise, see RICHARD H. FALLON, John F. Manning, Daniel J. Meltzer \& David L. Shapiro, Hart \& Wechsler's The FEDERAl Courts AND THE Federal System 7-9 (6th ed., 2009). See also FARRAND, supra note I 75, at 79-80 ("The most serious question was that of the inferior courts. The difficulty lay in the fact that they were regarded as an encroachment upon the rights of the individual states. .. [T]he matter was compromised: inferior courts were not required, but the national legislature was permitted to establish them.").

181 See generally FARRAND, supra note I75, at 9I-II2 (describing the "Great Compromise" that resulted in equal representation in the Senate). The delegates spent almost three weeks debating the mode of representation in Congress without a solution, "and the convention was on the point of breaking up." Id. at 94. After the Convention resolved that representation in the lower branch of the legislature would be proportional to population, the Convention deadlocked in a tie vote over a motion that each state receive equal representation in the upper branch. Id. at 96 . Since this tie left the Convention "at a standstill," the delegates formed a committee composed of one member from each state to reach a compromise and report back. Id. at 97-98. Although "[l]ittle is known of what took place in the committee," it ultimately reported out a proposal providing for proportional representation in the House and equal representation in the Senate. Id. at 98-99. After protracted debate lasting more than a week, the Convention eventually approved the compromise by a five to four vote, with Massachusetts divided and New York absent. See id. at I04-05. As Farrand explains: "This is the great compromise of the convention and of the constitution. None other is to be placed quite in comparison with it." Id. at I05. 
document presented to the ratifiers embodied quite a number of careful and rather explicit decisions about the contours of a national government and its relationship to the states. I cite the foregoing examples not to establish the basis for particular compromises (which would have been unknown to the ratifiers, in any case), but rather to establish the plausibility of understanding the abundant detail reflected in the Convention's end product as itself being the product of compromise. ${ }^{182}$

Third, whenever a lawmaking process conditions its end product on the satisfaction of carefully specified stakeholders (as such processes almost invariably do), it would make nonsense of the underlying process if interpreters disregarded apparently bargained-for outcomes. If the process assigns to certain actors the power to block lawmaking by withholding their assent, the same process also must be understood to permit those actors to condition their assent on the idea that the resultant law goes so far and no farther or that it has certain characteristics. This insight has, as discussed, gained considerable traction in the Court's statutory cases. ${ }^{183}$ It is more complicated but still true with respect to the adoption of the original document.

Like the legislative process, the constitutionmaking process conditions the exercise of lawmaking (or, at least, law-proposing) authority on arriving at proposals that satisfy specified stakeholders. Even if a constitution generally demands greater flexibility because of the long time frame that it governs and the broad subject matter typically covered, the fact remains that constitutionmakers, like other lawmakers, necessarily make judgments, whether conscious or not, about the level of generality at which they wish to frame their policies - whether to use rules or standards. In that way, the document's drafters have the latitude to leave some matters less precise and thus more susceptible to adaptation while insisting upon greater certainty and thus less flexibility for others. Consistent with that premise, some constitutional provisions are broad and sweeping; others read with the studied precision of the tax code. ${ }^{184}$

\footnotetext{
182 See infra section III.B, pp. 2048-55.

183 See supra section I.B, pp. 2013-20.

184 See Manning, supra note I36, at I 705-08. The most famous example of deliberate precision is Article II's requirement that the President shall "have attained to the Age of thirty five Years." U.S. ConST., art. II, § I, cl. 5. As Judge Posner has explained, "American lawyers recognize [that rule] as part of a family of rules that establish arbitrary eligibility dates in preference to making eligibility turn on uncertain qualitative judgments." Richard A. Posner, Legal Formalism, Legal Realism, and the Interpretation of Statutes and the Constitution, 37 CASE W. RES. L. REV. I79, I9I (I986). Some believe that even the age requirement for becoming President is not determinate. See, e.g., Gary Peller, The Metaphysics of American Law, 73 CAL. L. REV. I I5 I, I I 74 (I985); Mark V. Tushnet, A Note on the Revival of Textualism in Constitutional Theory, 58 S. CAL. L. REV. 683, 686-88 (I985). For reasons discussed above, I start from what I think to be a reason-
} 
The Philadelphia Convention carefully selected the ground rules by which it would act. The delegates agreed that at the Convention each state would participate on the basis of equal representation (with each state delegation to decide collectively how to cast its vote), and at least some evidence indicates that a different arrangement was rejected out of hand because of the danger that it would threaten the success of the proceedings. ${ }^{185}$ The equal representation of the small states in the Convention thus gave their constituents a disproportionate say in the shape of the Constitution. ${ }^{186}$ In addition, although decisions about how the document was to be ratified were deferred until the end, there is reason to assume that the delegates bargained with the expectation that they would have to secure the assent of a large proportion (if not all) of the states. ${ }^{187}$ Whatever the precise set of expectations about ratification, the document's final contours, at a minimum, reflected a distribution of bargaining power that gave the small states leverage that was out of proportion to their populations. ${ }^{188}$

Enforcing the spirit rather than the letter of a document devalues the fundamental decision to design the bargaining process a particular way. As discussed below, the stakeholding states (through their delegates) exercised their allocated voting power to adopt a document that, in many respects, divided power between the state and federal sovereigns rather precisely. They agreed not merely on the goal of concurrent sovereignty, but on a number of particular ways of achieving that goal. Indeed, to say that they adopted a system of federalism (in the abstract) is no more accurate than to say that they adopted a system of

able assumption about the existence of a social and linguistic community that is capable of framing intelligible commands and doing so at varying levels of generality. See supra note 72 .

185 See FARRAND, supra note $\mathrm{I} 75$, at 57 . As Farrand writes:

The Pennsylvania delegates ... urged "that the large States should unite in firmly refusing to the small States an equal vote, as unreasonable, and as enabling the small States to negative every good system of Government." The Virginia delegates, however, succeeded in stifling the project for fear that it "might beget fatal altercations between the Id. large and small States."

186 See Elster, supra note 167 , at 369 ("The voting procedure at the Convention ... increased [the small states'] bargaining power for logrolling purposes.").

187 Had the Convention abided by the manner of ratification set forth in Article XIII of the Articles of Confederation, it would have required submission of the proposed Constitution "to Congress and the state legislatures for their unanimous approval." JACK N. RAKOVE, ORIGINAL MeAnings: Politics ANd IDEAs IN THE MAKING OF THE CONSTITUTION Io3 (ig96); see also Elster, supra note 167 , at 370 ("Although no ratification procedure was laid down in the convocation of the Convention, many assumed that the Constitution would eventually have to be ratified by the state legislatures. Reasoning from that premise, they argued that the Constitution ought to be tailored so as to be acceptable to those bodies.").

188 See Bradford R. Clark, Constitutional Compromise and the Supremacy Clause, 83 NotRE DAME L. REV. I42 I, I425 (2008) (stressing that the process used to draft and ratify the Constitution "meant that the smaller states — representing a minority of the population — could block proposals favored by the larger states — representing a majority of the population"). 
nationalism. To abstract the level of generality of a number of specific provisions to the purpose (federalism) that justified them is to deny that the stakeholders bargained about means as well as ends. That supposition is contrary to the facts.

Finally, it is true that the Philadelphia Convention merely proposed a document to be ratified by (at least three-quarters of) the states. So perhaps its compromises should matter less than the public understanding of the ratifiers who gave the document legal force. ${ }^{189}$ Indeed, the Philadelphia Convention made a deliberate choice not to make its notes available to the ratifiers, so that its deliberations could not have informed their understanding of the document. ${ }^{190}$ But it is important to distinguish, in this regard, the use of the Convention's proceedings as evidence of compromise and the recognition that the document submitted by the Convention reflected the fact of compromise. Certainly, the ratifiers did not hammer out the text themselves. But the compromises reached by the Convention and embodied in that text structured the ratifiers' authority and defined their choices, especially since Article VII provided that they had to vote up or down the bundle of compromises reflected in the document. The compromises reached by the Convention were a necessary step in the creation of the Constitution, even though its ultimate legal force depended on action by the people of the several states. The willingness of members of the Convention to participate in the enterprise was secured by ground rules concerning their participation rights, such as equal representation of states and unit voting. To abstract from the specific compromises reached by the Convention to their overall purposes would, therefore, devalue the right of the relevant stakeholders to invoke those participation rights to withhold their assent or to condition it upon terms. ${ }^{191}$

189 See, e.g., Leonard W. Levy, Seasoned Judgments: The American ConstituTION, RIGHTS, AND HISTORY 317 (I995) ("[A]s its ratification rather than its framing imbued the Constitution with its legitimacy, so ratifier intent rather than original intent (the understandings of the Framers) defined the text."); Raoul Berger, Jack Rakove's Rendition of Original Meaning, 72 IND. L.J. 619, 64I (I997) ("Of course, the Ratifiers were the more authoritative spokesmen where their views differed from those of the Framers.”); Charles A. Lofgren, The Original Understanding of Original Intent?, 5 CONST. COMMENT. 77, 79 (I998) ("[A]lthough the originators rejected the use of framer intent, they did not thereby envisage that constitutional interpretation would exclude consideration of original intent. Instead, they were clearly hospitable to the use of original intent in the sense of ratifier intent, which is the original intent in a constitutional sense.").

190 See WARren, supra note $\mathrm{r68}$, at 793-94; Henry Paul Monaghan, Stare Decisis and Constitutional Adjudication, 88 COLUM. L. REV. 723, 725 (I988).

191 This scenario, it should be added, is not terribly different from a quite typical aspect of the legislative process. If the House and Senate vote for different versions of proposed legislation, the differences are usually reconciled by a conference committee consisting of legislators from both Houses. See Walter J. Oleszek, Congressional Procedures and the Policy ProcESS $253-75$ ( 7 th ed. 2007). The composition of such committees and their operation reflect obvious commitments about who should be the stakeholders in reaching a compromise. The Speaker 


\section{B. Lines of Compromise in the Document}

The lines of compromise concerning the division of authority between state and federal governments is evident in text submitted to, and adopted by, the ratifiers. Indeed, one of the most striking features of the constitutional text is the particularity with which the document specifies the means through which the federal system is to be established. ${ }^{192}$ Not all of these provisions are precise; some, in fact, leave considerable room for interpretation. But the important point is that they represent many particular judgments about how to allocate power, not an undifferentiated adoption of freestanding federalism. (Nor, as I discuss below, does the Tenth Amendment alter that conclusion. ${ }^{193}$ ) Like the separation of powers, ${ }^{194}$ federalism is not a mere abstraction, but is woven into the document through a number of particular measures.

The following examples are meant not to provide an exhaustive list of the provisions that implement federalism, but rather to give a concrete sense of the elaborate means by which the document implements that background value. ${ }^{195}$ After describing the provisions that are concrete manifestations of federalism, I will briefly explore potential objections arising from the fact that some of the federalism provisions may be vague enough to permit the consideration of purpose, even under a textualist approach.

I. Our Federalism(s). - Although there are assuredly many ways to categorize the numerous constitutional provisions that limit federal power and safeguard the autonomy of the states, I think it fair to describe five basic categories of such clauses. First, although I will

of the House and the Majority Leader of the Senate select the conferees from the relevant committees, in consultation with the chairs and ranking minority members of the committee that reported the bill. The conferees from each House vote as a unit, so they have to agree among themselves and then with each other. See id. at 275 . Once the conference committee reaches agreement, a conference report containing the compromise is typically submitted to each House for an up-or-down vote. The fact that such a compromise is crafted in a committee that lacks authority to give legislation the force of law does not negate the fact that their agreement was essential to the bill's enactment. It would undermine the process no less if a court were to disregard the lines of compromise contained in the final text of a statute simply because they were proposed by a committee and merely ratified by the two Houses (and the President). See Manning, supra note 72 , at 2429-30 (discussing the importance of conference committee bargaining in understanding the nature of legislative compromise).

192 Detailed lawmaking is often taken to be evidence of compromise. See Frank H. Easterbrook, The Supreme Court, 1983 Term-Foreword: The Court and the Economic System, 98 HARV. L. REV. 4, I6 (I984).

193 See infra pp. 2063-65.

194 See infra note 288 and accompanying text.

195 For a particularly thoughtful exposition of the relevant particulars, see DAVID L. SHAPIRO, FEDERALISM: A DiAlogue 58-64 (1995) (detailing the textual and historical bases for federalism in the Constitution). 
shortly say more about the obvious ambiguities in specific provisions of Article I, Section 8, the fact remains that the basic shape and contours of that provision supply rather clear evidence of line-item decisionmaking - the hallmark of bargained-for compromise. Whatever indeterminacy marks provisions such as the General Welfare Clause, the Commerce Clause, or the Necessary and Proper Clause, ${ }^{196}$ the balance of Section 8 leaves little doubt that the drafters and adopters of Article I established a system of enumerated powers and made rather specific judgments about what constituted appropriate matters of federal concern. ${ }^{197}$ Even focusing on subjects that touch on gainful activity, consider the extraordinary level of detail involved in the specification of power "[t]o establish... uniform Laws on the subject of Bankruptcies"; "[t]o coin Money, regulate the Value thereof, and of foreign Coin, and fix the Standard of Weights and Measures"; "[t]o provide for the Punishment of counterfeiting the Securities and current Coin of the United States"; "[t]o establish Post Offices and post Roads"; and "[t]o promote the Progress of Science and useful Arts, by securing for limited Times to Authors and Inventors the exclusive Right to their respective Writings and Discoveries."198 The careful attention to detail in these clauses indicates a design to promote the goal of federalism through the specific means of enumerating limited and defined federal powers.

Second, "Article I also fortifies the states by protecting them from each other and from the federal government." 199 The Constitution implements the goal of federalism by specifying substantive limits on federal power to regulate matters within the states. Among them, Article I, Section 9 specifies that "[n]o Tax or Duty shall be laid on Articles exported from any State," and that "[n]o Preference shall be given by any Regulation of Commerce or Revenue to the Ports of one State over those of another." 200 And the federal government may impose "[n]o

\footnotetext{
196 See U.S. CONST. art. I, § 8, cls. I, 3, I8.

197 For the argument that the specification was intended not to create a negative implication but to guard against narrow construction of federal power, see Deborah Jones Merritt, The Third Translation of the Commerce Clause: Congressional Power To Regulate Social Problems, 66 GEO. WASH. L. REV. I206, I2 IO-I I (I998). I proceed here on the reasonable assumption that the conventional explanation for the enumeration - as limiting the number and scope of federal powers - is correct. For a defense of that proposition based on a close analysis of the structure of Article I, see Martin H. Redish \& Karen L. Drizin, Constitutional Federalism and Judicial Review: The Role of Textual Analysis, 62 N.Y.U. L. REV. I, I3-I5 (1987).

198 U.S. CONST. art. I, § 8, cls. 4-8.

199 SHAPIRO, supra note I95, at 60

200 U.S. CONST. art. I, § 9, cls. 5-6.
} 
Capitation, or other direct, Tax," except in proportion to the population of the respective states. ${ }^{201}$

Third, the original Constitution assigns the states a number of important responsibilities with respect to the selection of key federal officials, including members of Congress and the President. ${ }^{202}$ Although subsequently superseded by the Seventeenth Amendment's provision for a system of popular election, ${ }^{203}$ Article I, Section 3 provided that the Senate "shall be composed of two Senators from each State, chosen by the Legislature thereof." ${ }^{204}$ In addition, electors for the House of Representatives were to have "the Qualifications requisite for Electors of the most numerous Branch of the State Legislature," giving the states some degree of control over the suffrage for federal office. ${ }^{205}$ The state legislatures, moreover, possess the presumptive authority to set "[ $t$ ]he Times, Places, and Manner of holding Elections for Senators and Representatives."206 And, of course, Article II provides that "[e]ach State shall appoint" presidential electors "in such Manner as the Legislature thereof may direct." 207 These provisions, individually and cumulatively, confer upon the states a degree of protection against federal overreaching by allowing the states an explicit (though sometimes defeasible) say in the manner of composing the federal government.

Fourth, the document places some limits and some obligations upon the federal sovereign respecting the physical and political integrity of the states as such. Article IV, for example, permits Congress to admit new states into the Union, but provides that "no new State shall be formed or erected within the Jurisdiction of any other State; nor [shall] any State be formed by the Junction of two or more States, or Parts of States, without the Consent of the Legislatures of the States concerned as well as of the Congress." ${ }^{208}$ The same Article later obliges the federal sovereign to "guarantee to every State . . . a Republican Form of Government, and [to] protect each of them against Invasion; and on Application of the Legislature, or of the Executive (when the Legislature cannot be convened) against domestic Violence."209 Al-

201 Id. cl. 4; see also Loughborough v. Blake, I8 U.S. (5 Wheat.) 3I 7, 32 I (I820) (explaining that the purpose of the clause is to ensure apportionment of direct taxes in proportion to state population).

202 See Herbert Wechsler, The Political Safeguards of Federalism: The Role of the States in the Composition and Selection of the National Government, 54 COLUM. L. REV. 543, 546-47, 558 (I954).

203 U.S. CONST. amend. XVII.

204 Id. art. I, § 3, cl. I.

205 Id. $\$ 2$, cl. I.

206 Id. $\$ 4$, cl. I.

207 Id. art. II, § I, cl. 2.

$208 I d$. art. IV, $\S 3$, cl. I.

209 Id. $\S 4$. 
though reasonable people can differ about what the Guarantee Clause means - and about whether it provides affirmative protection for states against federal power ${ }^{210}$ - the fact remains that the clause establishes a framework for analysis, not just a general grant of authority to articulate the requirements of a federal system.

Fifth, much of the lawmaking apparatus reflects a conscious design to protect states against promiscuous or harmful federal lawmaking. As Professor Bradford Clark emphasizes, the Supremacy Clause specifies the types of federal law - "[t]his Constitution, and the Laws ... which shall be made in pursuance thereof; and all treaties made, or which shall be made, under the Authority of the United States" - that count as "the supreme Law of the Land" and bind state judges. ${ }^{211}$ Each type of law specified in that clause builds on what Professor Herbert Wechsler calls the "political safeguards of federalism." 12 Provisions of "[t]his Constitution" required ratification by no fewer than three-quarters of the states under Article VII, and the amendment process under Article $\mathrm{V}$ typically demands the assent of two-thirds of the House and the Senate and always requires ratification by three-quarters of the states. ${ }^{213}$ "Laws" enacted pursuant to the bicameralism and presentment requirements of Article I, Section 7 of course require the concurrence of the Senate. ${ }^{214}$ Finally, under Article II, Section 2, Clause 2, the adoption of treaties depends on the President's securing the advice and consent of two-thirds of the Senate. ${ }^{215}$ In each case, therefore, the lawmaking procedure required the assent of a supermajority of the states directly (Articles V and VII) or the assent of the Senate or both. Indeed, the timing of the Supremacy Clause's adoption coincided precisely with the Great Compromise providing for equal state representation in the Senate - further reinforcing the premise that the forms of law specified in the Supremacy

\footnotetext{
210 For a thoughtful analysis suggesting that the Guarantee Clause provides certain affirmative limits on federal power to interfere with states' methods of structuring and operating their governments, see Deborah Jones Merritt, The Guarantee Clause and State Autonomy: Federalism for a Third Century, 88 COLUM. L. REV. I, 29-36 (I988), which finds support for that proposition in the ratification debates.

211 U.S. CONST. art. VI, cl. 2; see Clark, supra note 58, at I338-39.

212 See generally Wechsler, supra note 202.

213 See U.S. ConsT. arts. V, VII; see also Clark, supra note 58, at I33 I.

214 Professor Clark thus emphasizes that the terminology of Article I, Section 7 refers to the enactment of "a Law." See Clark, supra note 58, at I332. Article I, Section 7 provides that "[e]very Bill which shall have passed the House of Representatives and the Senate, shall, before it become $a$ Law, be presented to the President of the United States." U.S. CONST. art. I, § 7, cl. 2 (emphasis added). If the President signs the bill, it becomes a law. But "if not he shall return it, with his Objections to that House in which it shall have originated." Id. In that case, if twothirds of each House votes to override his or her veto, it can also "become a Law." Id. (emphasis added).

215 See U.S. Const. art. II, § 2, cl. 2; see also Clark, supra note 58, at I332.
} 
Clause were meant to tap into processes in which the interests of the small states received explicit and disproportionate protection. ${ }^{216}$ Whether or not one accepts the bolder claim that the Supremacy Clause made those methods of lawmaking fully exclusive, ${ }^{217}$ at a minimum the explicit role of the states in those three important lawmaking processes provides an obvious means of safeguarding federalism.

2. Vagueness, Purpose, and Compromise. - Based on the foregoing provisions, it is difficult not to conclude that the founders came to terms upon a number of particular provisions prescribing varied means of allocating governmental power, rather than adopting federalism in the abstract. This conclusion holds, moreover, even though some of the "particular" provisions - including, perhaps most prominently, the Commerce Clause and the Necessary and Proper Clause are not themselves terribly precise. Such clauses invite at least two questions about my central thesis. First, does their open-endedness make the document appear more like one embracing broad principles than one based on multiple compromises? Second, if textualists believe, as they do, that such open-ended clauses permit the consultation of background purpose (when reliably discernible), does that fact contradict the idea that the document does not adopt purposes in the abstract? The answer to these questions, if anything, clarifies the central idea that texts articulate policy or purpose at many different levels of generality and that the interpreter should respect (rather than shift) the agreed-upon level of generality, whether it be precise or more openended. To acknowledge that clauses like the Commerce Clause or the Necessary and Proper Clause leave room for interpretation is worlds apart from concluding that the Constitution adopts a general federalism norm distinct from any particular clause.

216 See Bradford R. Clark, Constitutional Compromise and the Supremacy Clause, 83 NOTRE DAME L. REV. I42 I (2008) (linking the compromises that gave rise to equal representation in the Senate and the adoption of the Supremacy Clause).

217 Professor Peter Strauss has raised several objections to Professor Clark's thesis about the exclusivity of the Supremacy Clause. See Peter L. Strauss, The Perils of Theory, 83 Notre DAME L. REV. I 567 (2008). To name one: the Supremacy Clause makes the enumerated categories of federal law supreme, "any Thing in the Constitution or Laws of any State to the Contrary notwithstanding." U.S. ConsT. art. VI, cl. 2 (emphasis added). Professor Strauss argues that unless federal law cannot preempt state common law, the term "Laws" as used in the foregoing clause must include state common law. See Strauss, supra, at $1567-73$. On this account, Professor Clark's reading requires the term "Laws" to have one meaning in the first part of the Supremacy Clause ("Laws of the United States which shall be made in Pursuance" of this Constitution) and a different one in the final part describing what is preempted. See id. at I568-69. Professor Clark responds that "Constitution or Laws of any State" need not refer to common law because the states received the common law by adopting reception statutes or constitutional provisions. See Bradford R. Clark, The Procedural Safeguards of Federalism, 83 NOTRE DAME L. REV. I68I, I685 (2008). Adjudication of this debate, however, is beyond this Article's scope. 
First, consider the example of the Commerce Clause (I will have more to say about the Necessary and Proper Clause below). ${ }^{218} \mathrm{Al}-$ though some would say that the clause leaves little to the imagination, ${ }^{219}$ I think it fair to read the clause as one of a family of clauses that leaves interpreters significant discretion to develop implementing doctrine - doctrine that does not flow neatly from premises derived from the text. ${ }^{220}$ Certainly, the elaborate and shifting tests that the Court has struggled to articulate and apply in its Commerce Clause cases, both before 1937 and more recently, suggest as much. ${ }^{221}$

But the mere fact that a clause leaves its interpreters significant discretion does not negate the possibility that it was part of a bargained-for outcome. A legislative outcome may leave discretion to interpreters for many reasons: lawmakers may be unable to agree on a more precise formulation; they may wish to delegate power to another institution to flesh out the details; or they may not appreciate the indeterminacy that they have produced. ${ }^{222}$ Bargained-for texts address problems at different levels of generality. As noted, one assuredly sees such diversity in abundance in the Constitution itself. ${ }^{223}$ Assuming that the Commerce Clause does assign interpreters significant discretion, the terms and historical context of the clause can still channel and constrain the range of factors that an interpreter should consider in ex-

218 On the Necessary and Proper Clause, see infra pp. 2062-63.

219 For example, Professor Richard Epstein argues that various textual, structural, and historical cues demonstrate that the clause pertained only to the regulation of trade or transportation that crossed state lines. See Richard A. Epstein, The Proper Scope of the Commerce Power, 73 VA. L. REV. I387 (I987). Some would resist that characterization of the Commerce Clause. Professor William Winslow Crosskey, for example, argues that the clause clearly provides something approaching police power because the founding generation would have understood the word "among" in "Commerce among the several States" to mean "all the 'Commerce' to which the people of the United States had access," I William Winslow Crosskey, Politics AND THE CONSTitution IN THE History OF THE United States 83 (I953), an understanding that would permit federal regulation of intrastate activities. See generally id. at 50-II4.

220 See Richard H. Fallon, Jr., The Supreme Court, I9g6 Term-Foreword: Implementing the Constitution, I I I HARV. L. REV. 54, 57 (1997) (noting that some constitutional "norms" are "too vague to serve as rules of law" and that "their effective implementation requires the crafting of doctrine by courts").

221 See supra pp. 2020-25.

222 In the statutory context, this idea is captured by Chevron U.S.A., Inc. v. Natural Resources Defense Council, Inc., 467 U.S. 837 (I984), in which the Court offered the following explanation for why Congress might enact an open-ended statute:

Perhaps [Congress] consciously desired the [agency] to strike the [specific policy] balance... thinking that those with great expertise and charged with responsibility for administering the provision would be in a better position to do so; perhaps it simply did not consider the question at this level [of specificity]; and perhaps Congress was unable to forge a coalition on either side of the question, and those on each side decided to take their chances with the scheme devised by the agency. For judicial purposes, it matters not which of these things occurred.

Id. at 865 .

223 See supra p. 2040. 
ercising that discretion. Presumably, such an inquiry would focus, as it traditionally has, on what constitutes commerce, what criteria determine whether it can be considered interstate, and what purposes the clause itself (as opposed to the Constitution in gross) was meant to serve. However broad the Commerce Clause inquiry might be, it would entail a significant upward shift in the level of generality to go from arguing about what constitutes "Commerce among the several States" to asking how power should be divided in our federal system.

Second, one can with consistency subscribe to the notion that the founders adopted particular means rather than general purposes, even if textualist judges might appropriately construe an open-ended provision, such as the Commerce Clause, in light of available evidence of purpose. Textualists do not hesitate to construe a particular provision in light of its background purpose if that purpose can be identified from reliable sources at a meaningfully determinate level of generality. ${ }^{224}$ Though my conclusions are necessarily tentative here, the idea that the founders adopted a system of federalism or concurrent sovereignty strikes me as too abstract to do much work in figuring out the particular meaning of the Commerce Clause. It is possible, of course, that aspects of the document may reveal a clarifying purpose at a lower level of generality. For example, if the careful enumeration of powers in Article I, Section 8 suggests that the document, at least as originally understood, did not confer upon Congress a plenary police power, that conclusion might help the Court to reject an interpretation that would effectively reject all limits on the reach of the Commerce Clause and, hence, of federal power. ${ }^{225}$ That interpretive move is

224 See supra p. 20I8. Although textualists tend to distrust certain extrinsic sources of purpose (such as legislative history), they believe that purpose may be discerned from sources that include a statute's structure or the goals apparent from the text itself. See, e.g., United States v. Fausto, 484 U.S. 439, 448 (I988) (Scalia, J.) (deriving purpose from the structure of the Civil Service Reform Act). Along these lines, Professor Max Radin, though not a textualist, relevantly observed: "In the case of statutes ... it is rare indeed that we can not say positively what any particular statute is for, by reading it." Radin, supra note $6 \mathrm{I}$, at 876 .

225 See, e.g., United States v. Lopez, 5 I4 U.S. 549, 564 (I995) ("[I]f we were to accept the Government's arguments, we are hard pressed to posit any activity by an individual that Congress is without power to regulate.”); A.L.A. Schechter Poultry Corp. v. United States, 295 U.S. 495, 546 (I935) ("If the commerce clause were construed to reach all enterprises and transactions which could be said to have an indirect effect upon interstate commerce, the federal authority would embrace practically all the activities of the people and the authority of the State over its domestic concerns would exist only by sufferance of the federal government.").

Under textualist premises, it is not perfectly clear that even the modest purpose to adopt a system of limited and enumerated powers would prevail if the text is framed broadly enough to accommodate applications that the founders did not anticipate. If the economic integration of modern society has sapped the phrase "Commerce among the States" of significant filtering capacity, it is not self-evident why the Court should credit the founders' background expectations over the fair implications of the broad text they adopted (assuming that the implications are fair). As the Court has said in a statutory case, "it is ultimately the provisions of our laws rather than the 
hardly equivalent to embracing a freestanding federalism norm, abstracted from the multiple clauses that protect state autonomy in concrete ways.

\section{The Constitution and Nationalism}

Like almost any enacted text, the Constitution's structural provisions reflect cross-cutting purposes. If one purpose of the document is to preserve state autonomy, another is to nationalize governmental power. $^{226}$ Looking at the precise mischiefs that underlay the document's adoption (a classic move of purposivism), ${ }^{227}$ few would dispute that a central aim of the Philadelphia Convention was to adopt a national government with more effectual authority than the Congress then possessed under the Articles of Confederation.28 More important, while it is unnecessary to catalogue every provision that evinces a nationalizing impulse, it is worth noting several general provisions that obviously manifest such a purpose. ${ }^{229}$

While the Supremacy Clause may impose implicit limits on federal preemptive power, it also makes explicit that federal law is supreme within that sphere and trumps contrary state law, whatever its source. $^{230}$ Article I, moreover, assigns Congress such lawmaking pow-

principal concerns of our legislators by which we are governed." Oncale v. Sundowner Offshore Servs., Inc., 523 U.S. 75, 79 (I998) (Scalia, J.). It is not necessary here to resolve whether an interpreter should enforce a reasonably identifiable original purpose when it conflicts with the way a conventional reading of the text applies to changed or unforeseen circumstances. For a brief discussion of the related problems of translation and of compensating adjustments, see infra section III.E, pp. 206I-67.

226 See Hills, supra note 93, at 5 (noting that a broad invocation of "federalism" as "an important value in the American constitutional scheme" can be "too general" because "nationalism is also a constitutional value"); Carlos Manuel Vázquez, The Separation of Powers As a Safeguard of Nationalism, 83 NOTRE DAME L. REV. I60I, I604 (2008) (arguing that the constitutional structure seeks to strike "a balance between federalism and nationalism").

227 The classic citation for this technique of course is Heydon's Case, 3 Co. Rep. 7 a, 76 Eng. Rep. 637, 638 (Exch. 1584), which directs courts to interpret a statute to suppress the "mischief and defect" leading to its passage.

228 See FARRAND, supra note I 75, at I-I3 (describing the events leading up to the Philadelphia Convention); WARREN, supra note I68, at 5 (noting that the "actual evils which led to the Federal Convention of $\mathrm{I} 787$ are familiar to every reader of history" and that these evils arose "from lack of power in the Government of the Confederation to legislate and enforce at home such authority as it possessed").

229 For an excellent discussion of the text and history supporting a nationalist reading of the Constitution, see SHAPIRO, supra note I95, at I4-26.

230 U.S. ConsT. art. VI, cl. 2. As Chief Justice Marshall wrote in $M c$ Culloch v. Maryland, I 7 U.S. (4 Wheat.) 3 I6 (I8I9):

If any one proposition could command the universal assent of mankind, we might expect it would be this - that the government of the Union, though limited in its powers, is supreme within its sphere of action. This would seem to result necessarily from its nature. It is the government of all; its powers are delegated by all; it represents all, and acts for all... . But this question is not left to mere reason: the people have, in express terms, decided it, by saying, "this constitution, and the laws of the United States, 
ers as are "necessary and proper for carrying into Execution the foregoing Powers, and all other Powers vested by this Constitution in the Government of the United States, or in any Department or Officer thereof." 231 Although that clause certainly lends itself to a narrow reading that permits Congress to enact laws essential to the pursuit of ends lying within an enumerated power, ${ }^{232}$ it also admits of a more expansive reading - one that gives Congress considerable latitude concerning the choice of means to achieve the enumerated ends. ${ }^{233}$ However much latitude the Necessary and Proper Clause allows, the clause seems obviously calculated, at the very least, to eliminate any doubt that Congress possesses meaningful implemental powers that go beyond the literal terms of the enumerated powers. ${ }^{234}$

Finally, the document imposes explicit limitations on state power with an eye toward consolidating national authority over particular subject matter areas. In an apparent effort to consolidate national power over foreign relations, Article I, Section io provides that states may not "enter into any Treaty, Alliance, or Confederation" or "grant Letters of Marque and Reprisal." 235 A similar set of provisions in the same section limits states' capacities to make monetary policy: they may not "coin Money; emit Bills of Credit; [or] make any Thing but gold and silver Coin a Tender in Payment of Debts."236 Clause 2 then forbids states, without congressional consent, to "lay any Imposts or

which shall be made in pursuance thereof," "shall be the supreme law of the land," and by requiring that the members of the State legislatures, and the officers of the executive and judicial departments of the States, shall take the oath of fidelity to it. Id. at $405-06$.

231 U.S. Const. art. I, $\S 8$, cl. I8.

232 Then-Representative James Madison offered the clearest and most elegant exposition of that position during the debate over the First Bank of the United States during the First Congress. See Randy E. Barnett, The Original Meaning of the Necessary and Proper Clause, 6 U. PA. J. CONST. L. I83, I88-94 (2003) (detailing the position taken by Madison in the debate).

233 As Chief Justice Marshall wrote in I805, "Congress must possess the choice of means, and must be empowered to use any means which are in fact conducive to the exercise of a power granted by the constitution." United States v. Fisher, 6 U.S. (2 Cranch) 358, 396 (I805).

234 As Madison pointed out (to different effect) during the debate over the Bank of the United States, the enumerated powers of Article I themselves contain some quite specific implemental provisions. See 2 ANNALS OF CONG. I949 (I79I) (discussing implemental aspects of particular enumerated powers and arguing that the specificity of the particular means of implementation contradicted the notion of a free-floating power under the Necessary and Proper Clause). Presumably, the power "[t]o provide for the Punishment of counterfeiting the Securities and current Coin of the United States" supplies a means of implementing the adjacent power "[t]o coin Money, [and] regulate the Value thereof." U.S. CONST. art. I, § 8, cls. 5-6. Similarly, the power "[t]o make Rules for the Government and Regulation of the land and naval Forces" might be understood to implement the nearby powers "[t]o raise and support Armies" and "[t]o provide and maintain a Navy." Id. cls. I2-I4. Whether understood more strictly or more liberally, the Necessary and Proper Clause thus reflects a self-conscious choice to create a general implemental authority rather than specify all appropriate congressional means on a clause-by-clause basis.

235 U.S. CONST. art. I, § Io, cl. I.

236 Id. 
Duties on Imports or Exports, except what may be absolutely necessary for executing it's inspection Laws."237 Finally, Clause 3 provides a detailed set of restrictions that effectively deny states a broad swath of customary authority over foreign and military affairs. ${ }^{238}$

Just as the provisions described in section III.B. I collectively suggest a purpose to preserve state sovereignty, the provisions discussed here plausibly evince an overall purpose to promote nationalism. ${ }^{239}$ Accordingly, the "spirit" underlying the document as a whole cuts in more than one direction. And mediation of the tension between the pro-federalism and nationalizing impulses must be found in the particulars through which the balance was struck. As the Court once put it: "The concept [of 'Our Federalism'] does not mean blind deference to 'States' Rights' any more than it means centralization of control over every important issue in our National Government and its courts. The Framers rejected both these courses."240 If that description is correct, then invocations of federalism cannot help judges draw particular lines between federal and state power in cases that do not turn on the meaning of particular constitutional clauses. ${ }^{241}$

237 Id. cl. 2. This provision, in fact, provides even greater detail. It states that the "net Produce of all Duties and Imposts, laid by any State on Imports and Exports, shall be for Use of the Treasury of the United States; and all such Laws shall be subject to the Revision and Controul of the Congress." Id.

238 The clause reads:

No State shall, without the Consent of Congress, lay any Duty of Tonnage, keep Troops,

or Ships of War in time of Peace, enter into any Agreement or Compact with another

State, or with a foreign Power, or engage in War, unless actually invaded, or in such

imminent Danger as will not admit of delay. Id. cl. 3 .

239 In addition, Professor David Shapiro notes that particular clauses preserved - in one example, infamously - certain measures of state autonomy while also recognizing new congressional powers:

[T]he training of the militias and the appointment of officers are reserved to the states (although Congress is expressly given the authority to prescribe the appropriate discipline and also - in separate clauses of Article I, $\S 8-$ to establish a national army and navy, to call forth the militia, and to declare war). And in Article I, $\$ 9$, Congress is precluded from preventing "migration or importation" of persons into the states until I 808 (the infamous provision that authorized continued importation of slaves but that notably permitted Congress to stop all such immigration in less than 20 years) .... SHAPIRO, supra note I95, at ig (footnote omitted).

240 Younger v. Harris, 40I U.S. 37, 44 (I97I).

241 Along similar lines, if the Court wishes to employ a purposive, generality-shifting approach to determine the proper scope of federalism, it should presumably also factor in the nationalizing purposes underlying the Civil War Amendments. Cf. Richard H. Fallon, Jr., The Ideologies of Federal Courts Law, 74 VA. L. REV. I I4I, II59 (I988) ("According to a Nationalist theory, state sovereignty ... must be viewed as vastly diminished, if not eviscerated, by the Reconstruction amendments, at least insofar as it is invoked to frustrate the enforcement of federal constitutional rights."); Gene R. Nichol, Jr., Federalism, State Courts, and Section 1983, 73 VA. L. REV. 959, 960 (I987) ("The provisions of the Civil War amendments promised a significant revision in concepts of state sovereignty."). 


\section{The Cases Revisited}

The new federalism cases rest on the idea that the United States Constitution adopts a system of federalism, in which the states retain some attributes of sovereigns and cede others. Although certainly correct, the structural insight at that level of generality is hopelessly uninformative. To say that the Constitution embodies federalism is true in the same sense in which it is true that the Constitution embodies the principles of personal privacy, ${ }^{242}$ private property, ${ }^{243}$ and even the separation of powers when invoked as a freestanding concept. ${ }^{244}$ Each assertion describes goals that the document's drafters set out to achieve, but each also abstracts the purpose underlying specific constitutional provisions to an unhelpful level of generality, one that disregards the specification of means by which its adopters sought to achieve such purposes.

To be fair, the Court's new federalism cases go beyond exclusive reliance on federalism, understood at that high level of generality. But it is hard to deny that abstraction from (a) individual clauses that divide national and state powers in specific ways, to (b) a general purpose of federalism, plays a pivotal role in the Court's analysis. ${ }^{245}$ None of the cases identify a specific textual source of the asserted limitation on federal power, ${ }^{246}$ and two of the opinions (those in Printz and Alden) disclaim reliance on any particular constitutional provision. ${ }^{247}$ Hence, when the Court in these cases invoked preconstitutional tradition, the legislative history of the Convention and the ratifying debates, or postconstitutional practice, its conceptual hook was that the document's

\footnotetext{
242 See Griswold v. Connecticut, 38I U.S. 479 (1965) (deriving a generalized right of privacy from various clauses that protect that value).

243 See RichARD A. EPSTEIN, TAKINGS (I985) (abstracting broader Lockean principles from specific constitutional clauses).

244 See infra note 288 and accompanying text.

245 See supra Part II, pp. 2020-36.

246 As noted, all of the cases acknowledge that the Tenth Amendment confirms the background premises of limited federal power and state sovereignty. See Alden v. Maine, 527 U.S. 706, 713I4 (I999); Printz v. United States, 52 I U.S. 898, 919 (I997); New York v. United States, 505 U.S. I44, I55-57 (I992); Gregory v. Ashcroft, 50I U.S. 452, 463 (I99I). But none of the cases do, or could, suggest that the Tenth Amendment's general and externally referential language itself supplies the rule of decision upon which the Court rests. For further discussion of the Tenth Amendment, see infra pp. 2063-65.

247 See Alden, 527 U.S. at 7 I 3 (disclaiming the explicit text of the Eleventh Amendment as a source of state sovereign immunity and instead reasoning that "the Constitution's structure, its history, and the authoritative interpretations by this Court make clear" that "the States' immunity from suit is a fundamental aspect of the sovereignty which the States enjoyed before the ratification of the Constitution, and which they retain today ... except as altered by the plan of the Convention or certain constitutional Amendments"); Printz, 52 I U.S. at 905 (acknowledging that "there is no constitutional text speaking to [the] precise question" presented and concluding that the constitutional legitimacy vel non of commandeering would turn upon "historical understanding and practice, ... the structure of the Constitution, and ... the jurisprudence of this Court").
} 
provisions as a whole reflect a collective purpose to adopt federalism, which the Court has the authority to flesh out and to enforce. That approach, however, disregards the detailed provisions that make that idea operational.

Two considerations suggest that basic concerns about generality shifting may have special force in the context of federalism. First, American federalism seems to lack a clear preconstitutional antecedent capable of supplying a default position for understanding the division of governmental powers. ${ }^{248}$ The Constitution was modeled neither upon the loose-knit structure of the Articles of Confederation nor upon the centralizing impulse of the British Empire - the examples of compound government most familiar to the founders. ${ }^{249}$ In an era in which sovereignty was thought to be indivisible, ${ }^{250}$ the Constitution

248 The Court routinely relies on common law understandings to fill in the details of legal terms or concepts borrowed from the English tradition. See, e.g., Wilson v. Arkansas, 5 I4 U.S. 927 , 93 I-33 (1995) (relying on English common law in interpreting the Fourth Amendment); Ex parte Grossman, 267 U.S. 87, I08-Io (1925) (relying on English understanding of the Pardon Power). Early state practice sometimes also helps the Court to ascertain the benchmark against which the founders acted. See, e.g., Washington v. Glucksberg, 52 I U.S. 702, 7I2-I4 (I997) (relying on colonial and early state statutes prohibiting suicide as part of the basis for concluding that the right to die does not constitute a substantive due process right). The Court's textualists have no difficulty with the premise that interpreters should read technical words in their technical sense. Moskal v. United States, 498 U.S. I03, I 2 I (I 990) (Scalia, J., dissenting) ("[W]here Congress borrows terms of art in which are accumulated the legal tradition and meaning of centuries of practice, it presumably knows and adopts the cluster of ideas that were attached to each borrowed word in the body of learning from which it was taken and the meaning its use will convey to the judicial mind unless otherwise instructed." (alteration in original) (quoting Morrissette v. United States, 342 U.S. 246, 263 (I952) (Jackson, J.)) (internal quotation mark omitted)).

249 As Professor Akhil Amar writes:

The Philadelphia delegates thus had the benefit of two previous efforts to achieve a theoretically acceptable and practically workable federalism. The imperial model had proved unacceptable because it centralized all power, denying individual state governments any role as independent centers of authority. In the language of the time, it was a pure "consolidation" that "melted down" all states into one monstrous "common mass." It was too "national." The Articles of Confederation, on the other hand, had failed because there was insufficient gravitational pull from the center to counter the centrifugal tendencies of each state. The system was too "federal."

Akhil Reed Amar, Of Sovereignty and Federalism, 96 YALE L.J. I425, I448-49 (I987) (footnote omitted); see also Alpheus Thomas Mason, The Supreme Court and Federalism, 44 TEX. L. REv. I I87, i I 90 (I966) ("Needed was an overall common power - perhaps a 'medium' between absolute state independence and absolute subjection to a central authority. Could America find the 'middle ground' which the colonists and Britain alike considered a hopeless search?").

250 See Amar, supra note 249, at I430 ("A single nation could not operate with two sovereigns any more than a single person could operate with two heads; some single supreme political will had to prevail, and the only limitations on that sovereign will were those that the sovereign itself voluntarily chose to observe."); Mason, supra note 249 , at i I 90 ("The Revolutionary fathers deplored imperium in imperio, denouncing it a political monster subversive of all government."). The Empire of course satisfied the indivisible sovereignty requirement based on the theory, abhorred by the colonists, that all sovereignty resided in the King-in-Parliament. See Amar, supra note 249 , at $1444-45$. A confederation, in turn, qualified because "[u]nder traditional jurispru- 
embodied the innovation that the sovereign people(s) could delegate their authority on a limited basis to more than one government operating within the same territory. ${ }^{251}$ Because the delegation to the federal government was to be limited in scope, the states and the people thereof would retain significant residual powers, but the federal government's laws would be supreme within its delegated sphere. ${ }^{252}$ Thus, as Professor Jack Rakove has observed, "the new federal system would occupy a middle ground between a confederation of sovereign states and a consolidated nation." 253 Or, in Justice Kennedy's words, "[f]ederalism was our Nation's own discovery. ... [The] Constitution created a legal system unprecedented in form and design, establishing two orders of government ...."254 If those premises are correct, prior models of government have little, if anything, to reveal about the novel division of governmental powers proposed by the Philadelphia Convention and adopted by the ratifiers. ${ }^{255}$

dence, sovereign states could enter into treaties with one another, and might even join together in a perpetual federation, or league, without losing their sovereign status." Id. at I446.

251 See Amar, supra note 249, at I440. I refer to the "people(s)" to elide an important but, for present purposes, tangential debate about the true locus of sovereignty in our system of government. Some believe that sovereignty resides in the people of the nation. See, e.g., SHAPIRo, supra note 195, at I7 (noting that the "philosophical foundation" of the Constitution was "the ultimate sovereignty of the people of the United States"); Amar, supra note 249, at I449-50 (same). Others think that it lies, in whole or in part, in the people of the several states. See, e.g., U.S. Term Limits, Inc. v. Thornton, 5I4 U.S. 779, 846 (I995) (Thomas, J., dissenting) ("The ultimate source of the Constitution's authority is the consent of the people of each individual State, not the consent of the undifferentiated people of the Nation as a whole."); Henry Paul Monaghan, We the People[s], Original Understanding, and Constitutional Amendment, 96 COLUM. L. REV. I2 I, I38 (1996) ("A significant number of Americans simultaneously held — in varying mixtures and intensities - some concept of a 'We the People' of the United States and . . some concept of a 'We the People' of Delaware, and so on.”). For present purposes, the right answer, if one exists, matters little. As Amar has suggested, "the question whether the People of the state or of the Union were sovereign did not necessarily dictate the allocation of power between state and federal government." Amar, supra note 249, at I 454 .

252 See Herbert J. Storing, What the Anti-Federalists Were For 32-33 (I98I) (noting that the Federalists defended the Constitution in these terms and that the Anti-Federalists ultimately accepted that framework even while disputing the particulars); Powell, supra note 9I, at 655-56 (same); see also Fallon, supra note 91, at 442 ("[The American states] enjoy at most a residual sovereignty, consisting of such elements as remain after recognition of both the ultimate authority of 'the People' and the superior juridical status of the Constitution, laws, and treaties of the United States.").

253 RAKOve, supra note 187 , at $\mathrm{r} 68$. Consider also Madison's famous observation: "The proposed Constitution . . . is, in strictness, neither a national nor a federal Constitution, but a composition of both." The Federalist No. 39, at 246 (James Madison) (Clinton Rossiter ed., I96I).

254 Thornton, 5 I 4 U.S. at 838 (Kennedy, J., concurring). For a similar perspective, consider Michael W. McConnell, Federalism: Evaluating the Founders' Design, 54 U. CHI. L. REV. I484 (ig87) (reviewing RaOul Berger, Federalism: The Founders' Design (ig87)), which argues that our federalism "was a uniquely American blend of national systems - like the French — and confederate systems - like the ancient Greek and early modern Dutch.” Id. at I492.

255 For this reason, Professor Michael Rappaport's creative attempt to ground the new federalism cases in the common law understanding of the word "state" cannot ultimately carry the day. 
Second, and relatedly, federalism has no ideal type. ${ }^{256}$ The design of a federal system is not a matter of principle, but rather a decision about the allocation of political power. As Professor Vicki Jackson has written, many different nations have now adopted federal systems, but these systems differ significantly in the details of how they divide, structure, and limit the respective powers of each sovereign. ${ }^{257} \mathrm{Be}-$ cause "[n]o single feature defines this balance or relationship," Professor Jackson finds that "federalism arrangements embodied in constitutions are typically ... 'package deals."'258 And because the design of a federal system requires agreement about the allocation of power by existing political stakeholders, "federalism provisions are more likely to reflect hard-bargained-for compromises." ${ }^{259}$ Accordingly, it blinks reality for the Court to talk about freestanding federalism, as distinct from the many particular ways in which the founders chose to define and structure the relationships between the federal and state governments in the United States Constitution.

\section{E. A (Brief) Look at Alternative Theories}

This Article does not seek to consider whether the new federalism decisions are ultimately "right" or "wrong" in some sense, but rather to see what light they might shed on the use of purposive abstraction in constitutional adjudication. Nonetheless, I think it fair to pause over three potential alternative justifications. First, can the Necessary and Proper Clause supply a textual home for the Court's opinions? Second, might the Tenth Amendment provide a firm foundation for the

See Michael B. Rappaport, Reconciling Textualism and Federalism: The Proper Textual Basis of the Supreme Court's Tenth and Eleventh Amendment Decisions, 93 Nw. U. L. REV. 8I9 (I999). If the Constitution mixed and matched powers that had traditionally belonged indivisibly to sovereign "states," then the traditional definition of sovereignty cannot meaningfully inform the question of what residual powers remained in distinctly American "states" after the ratification of the Constitution. See Young, supra note 92, at $1624-26$ (suggesting that if one acknowledges, as one must, that an American "state" does not have the full measure of sovereignty, then the traditional attributes of sovereignty enjoyed by sovereign states cannot serve as a useful guide to the retained sovereign attributes of American states).

256 See, e.g., Epstein, supra note 2 I9, at I390-9I ("Jurisdiction [in the sense of the allocation of governmental power] is not part of ordinary moral discourse, or of our common understanding of right and wrong. Instead, jurisdiction is always regarded as a means towards an end rather than as an end in itself. ... Here there is no ... tradition of political philosophy upon which to draw."); Merritt, supra note 2 Io, at 3 ("The federal system resulted from a compromise between those who saw the need for a strong central government and those who were wedded to the independent sovereignty of the states.").

257 See Vicki C. Jackson, Comparative Constitutional Federalism and Transnational Judicial Discourse, 2 INT'L J. CONST. L. 9I, I04 (2004) ("Significant differences exist not only as to allocations and prohibitions of powers but also in the organization of the governmental structures of federal systems.").

258 Id. at 102.

259 Id. at 108. 
new federalism? Third, do the new federalism cases merely offer second-best, compensating adjustments for the dilution of protections that the states would have enjoyed had the Court not abandoned meaningful constraints on the Commerce Power after 1937? The first two questions merit consideration because they represent textual grounds to which the Court itself has at least made reference; ${ }^{260}$ the third deserves attention because it clarifies some of the assumptions and costs of a strictly textual approach. My aim here is not to analyze these complex questions exhaustively, but to suggest the beginnings of the necessary analysis.

First, Professor Gary Lawson and Patricia Granger argue that eighteenth-century Americans would have understood the word "proper" in the Necessary and Proper Clause to establish a jurisdictional limit upon legislative power - in effect, assigning the Court power to enforce unspecified background limits on the exercise of such power. ${ }^{261}$ Their historical evidence of founding attitudes is thorough and, if correct, gives the Court a potential textual basis for developing federalism doctrine. ${ }^{262}$ On that account, the Necessary and Proper Clause might be the general "federalism" clause whose existence I previously denied.

Even taking Lawson and Granger's analysis at face value, however, I tend to agree with Professor Ernest Young that their understanding of the term "proper" merely recognizes it as a vehicle for enforcing extratextual norms if the existence of those norms can otherwise be independently established. ${ }^{263}$ Lawson and Granger do not contend that the word "proper" was a term of art that carried antecedent, substantive connotations about the appropriate division of

\footnotetext{
260 A third potential textual ground is the Guarantee Clause. See Merritt, supra note 2 Io, at 29-36 (arguing that the ratifiers understood the Guarantee Clause to protect the states affirmatively from federal intrusion into state sovereignty). The Court's new federalism cases have never expressly relied on the Guarantee Clause. The Court twice raised the possibility of its relevance but then decided the cases on other grounds. See New York v. United States, 505 U.S. I44, I86 (I992) ("Thus even indulging the assumption that the Guarantee Clause provides a basis upon which a State or its subdivisions may sue to enjoin the enforcement of a federal statute, petitioners have not made out such a claim in these cases."); Gregory v. Ashcroft, 50 I U.S. 452, 463, 467 (I99I) (holding that the Guarantee Clause protects state authority "to determine the qualifications of their most important government officials" but deciding that Congress did not clearly signal its intention to interfere with that state function when it came to state judges). If, indeed, the Guarantee Clause imports relatively discernible limits on federal power to interfere with state functions, it would not present the same difficulties as freestanding federalism. But see Young, supra note 92 , at $1627-28$ (suggesting that the Guarantee Clause may simply invite interpreters to consider broader implications of the federal structure, as in the freestanding federalism cases).

261 Gary Lawson \& Patricia B. Granger, The "Proper" Scope of Federal Power: A Jurisdictional Interpretation of the Sweeping Clause, 43 DUKE L.J. 267, 29I-97 (I993).

262 See id. at 33I-32.

263 See Young, supra note 92, at I629 ("Lawson and Granger do not assert that the meaning of 'proper' can itself give content to those principles.").
} 
state and federal power. Hence, its utility as a freestanding source of judicially enforceable "federalism" depends entirely upon the Court's capacity to identify such a freestanding federalism norm, quite apart from the Necessary and Proper Clause. ${ }^{264}$ Consistent with that view, the new federalism cases have treated the Necessary and Proper Clause analysis as dependent upon the reasoning about federalism more generally, and have invoked it only by way of rebutting the government's reliance on the clause as an affirmative basis for the particular statute under review. ${ }^{265}$

Second, the Court's new federalism cases sometimes invoke the Tenth Amendment. The amendment of course states: "The powers not delegated to the United States by the Constitution, nor prohibited by it to the States, are reserved to the States respectively, or to the people." ${ }^{266}$ This language comes closer to adopting a freestanding federalism norm than does that of any other provision of the Constitution. And, as discussed, for many years prior to the Court's 1937 retreat from its earlier federalism doctrine, the Court routinely relied on the Tenth Amendment as an independent source of authority to enforce a tradition of dual sovereignty against Congress, even in cases involving powers that did not obviously lie outside of Article I. ${ }^{267}$

Ultimately, however, the Tenth Amendment cannot provide noncircular justification for the Court's freestanding federalism. ${ }^{268}$ Its language obviously reinforces the idea - already apparent from the text of Article I, Section 8 - that the Constitution adopts a system of limited and enumerated powers, and that all power claimed by the federal

264 Id. at I628-29; see also Prakash, supra note I2 7, at I994 (arguing that resort to the Necessary and Proper Clause "merely reformulates the question" whether commandeering of state executive officials "would violate implicit constitutional guarantees of state autonomy").

265 The Court's analysis, moreover, reflects the parasitic quality of relying on "proper" to enforce federalism. See, e.g., Printz v. United States, 52 I U.S. 898, 923-24 (1997) (holding that an Act of Congress is not "proper" when it "violates the principle of state sovereignty reflected in the various constitutional provisions"); Alden v. Maine, 527 U.S. 706, 732-33 (I999) (invoking the Necessary and Proper Clause in similar fashion).

266 U.S. CONST. amend. X.

267 See supra note 82.

268 See Young, supra note 92, at 1629 (noting that neither the Tenth Amendment nor the Necessary and Proper Clause can help the Court enforce limits on Congress's power "without employing "freestanding conceptions of state sovereignty"' (quoting Lawson \& Granger, supra note 26I, at 332)). For further development of the argument that the Necessary and Proper Clause and the Tenth Amendment serve similar functions, see Gary Lawson, A Truism with Attitude: The Tenth Amendment in Constitutional Context, 83 NOTRE DAME L. REV. 469, 472 (2008), which notes: The Bill of Rights, including the Tenth Amendment, in large measure simply reformulates the restrictions on federal power built into the Sweeping Clause. Laws therefore violate the Tenth Amendment when they interfere with the federalist structure of government in such a manner and to such an extent that they are not 'necessary and proper $I d$.

for carrying into Execution' national power. 
government must find its source in the authority thereby delegated. ${ }^{269}$ Although there has been historical disagreement about how strictly the amendment requires the enumeration to be enforced, ${ }^{270}$ the brute fact is that the Tenth Amendment's language is explicitly parasitic of a

269 See, e.g., Alden, 527 U.S. at $7 \mathrm{I} 4$ ("The Amendment confirms the promise [of enumerated powers] implicit in the original document...."); Printz, 52 I U.S. at 9 I9 ("Residual state sovereignty was also implicit, of course, in the Constitution's conferral upon Congress of not all governmental powers, but only discrete, enumerated ones, Art. I, § 8, which implication was rendered express by the Tenth Amendment[] . ..."). That view found frequent expression in the early days of the Republic. See, e.g., 3 Joseph Story, Commentaries on the Constitution of THE UNITED STATES $75^{2}$ (I833) ("This amendment is a mere affirmation of what, upon any just reasoning, is a necessary rule of interpreting the constitution. Being an instrument of limited and enumerated powers, it follows irresistibly, that what is not conferred, is withheld, and belongs to the state authorities ...."); James Madison, Speech in Congress Opposing the National Bank (Feb. 2, I79I), in JAMES MADISON: WRITINGS 480, 489 (Jack N. Rakove ed., I999) (noting that the Tenth Amendment prohibits the federal government from exercising any "source of power not within the constitution itself"); Letter From Edmund Randolph to George Washington (Feb. I2, I79I), in H. JefFerson POWell, The Constitution AND the AtTorneys General 3, 4 (I999).

270 One commentator believes that the Tenth Amendment requires strict construction of the enumerated powers - a position that would justify the new federalism cases and much more. See Kurt T. Lash, The Original Meaning of an Omission: The Tenth Amendment, Popular Sovereignty, and "Expressly" Delegated Power, 83 Notre DAMe L. REV. I889, I954 (2008). At least since McCulloch v. Maryland, I7 U.S. (4 Wheat.) 3I6, 363 (I8I9), however, the conventional wisdom (as Professor Lash acknowledges) has been to the contrary. Article II of the Articles of Confederation had provided that "[e]ach state retains its sovereignty, freedom, and independence, and every power, jurisdiction, and right, which is not by this confederation expressly delegated to the United States, in Congress assembled.” ARTICLES OF CONFEDERATION art. II (U.S. I78I). In $\mathrm{McC}$ ulloch, Chief Justice Marshall seized on the difference in wording between that provision and the Tenth Amendment to conclude that the latter does not require an express delegation of federal power. See I7 U.S. (4 Wheat.) at 406 ("[T] of quieting the excessive jealousies which had been excited, omits the word 'expressly,' and declares only, that the powers 'not delegated to the United States, nor prohibited to the states, are reserved to the states or to the people;' thus leaving the question ... to depend on a fair construction of the whole instrument.").

Despite $M c$ Culloch's ancient holding, Professor Lash emphasizes that although the amendment dropped the word "expressly," it added language specifying that undelegated powers were reserved not only to the states, but also "to the people." See Lash, supra, at i 924 . He argues that the founders would have understood this phrase to affirm popular sovereignty as the basis for the Constitution, and would have thought, under established conventions, that any delegation from the sovereign people to its agents must be strictly construed. See id. at I922-26.

If the founders had meant to retain the requirement of "express[]" delegation found in the Articles of Confederation, deleting the word "expressly" and adding the words "to the people" strikes me as an oblique way to do so (notwithstanding Professor Lash's plausible account of Madison's subjective purpose for proposing the change). See id. at I92 I-22. More importantly, Professor Lash's theory, even if correct, does not speak to my concerns about the Court's methodology in the new federalism cases. The Court has never suggested that the Tenth Amendment requires express delegation of federal powers. If, however, a particular phrase in the Tenth Amendment carried with it a background connotation of strict construction of the granted powers, the resulting norm would not reflect freestanding federalism but rather a specific understanding of an established legal convention. Such an approach, however, would for me face a heavy burden of persuasion, given the deeply embedded character of $\mathrm{McC}$ ulloch's approach. 
constitutional allocation of power made outside the amendment. ${ }^{271}$ It tells interpreters what to do with "[t]he powers not delegated to the United States by the Constitution," but alone contains literally no direction about how to ascertain what powers have been delegated. ${ }^{272}$ If notions of federalism can independently limit a delegation to the federal government, the Tenth Amendment of course picks up that limitation; if not, nothing in the amendment supplies the omission.

Third, an important strain of constitutional scholarship suggests that the new federalism may be justified as a form of "translation" of original commitments to modern circumstances, given the tremendous growth of federal power, at least since the New Deal. The basic concept of translation, developed by Professor Lawrence Lessig, rests on the idea that sometimes constitutional meaning changes quite dramatically because of the application of existing texts to changed contexts, and that fidelity may at times require interpreters to tweak the document to preserve original commitments in the face of such changed circumstances. $^{273}$ In the context of federalism, Professor Lessig notes that because of the vast growth of interstate commerce and the integration of the national economy, the scope of congressional power under the Commerce Clause grew to an extent "far greater than the framers imagined." 274 Even if that development represents a defensible expansion of power under the original understanding of opentextured provisions such as the Commerce Clause and the Necessary and Proper Clause, Professor Lessig stresses that the practical results have dispensed with "conventions and understandings[] presupposed by the framers." 275 If the original understanding of the scope of the

271 See, e.g., United States v. Darby, 3 I 2 U.S. I00, I24 (I94I) ("The amendment states but a truism that all is retained which has not been surrendered."); $f f$. McCulloch, I7 U.S. (4 Wheat.) at 363 "We admit, that the Ioth amendment to the constitution is merely declaratory; that it was adopted ex abundanti cautela; and that with it, nothing more is reserved, than would have been reserved without it."). Even if understood as a "truism," the amendment would still underscore the fact that one must identify a source of claimed federal power within the Constitution. See Fry v. United States, 42 I U.S. 542, 547 n.7 (I975) ("While the Tenth Amendment has been characterized as a truism . . . it is not without significance.") (internal quotations marks omitted).

272 See New York v. United States, 505 U.S. I44 (I992):

The Tenth Amendment . . . restrains the power of Congress, but this limit is not derived from the text of the Tenth Amendment itself, which ... is essentially a tautology. Instead, the Tenth Amendment confirms that the power of the Federal Government is subject to limits that may, in a given instance, reserve power to the States. The Tenth Amendment thus directs us to determine, as in this case, whether an incident of state sovereignty is protected by a limitation on an Article I power.

Id. at $156-57$.

273 See generally Lawrence Lessig, Fidelity in Translation, 7 I TEX. L. REV. I 65 (I993) (explaining and illustrating the theory of translation); Lawrence Lessig, Understanding Changed Readings: Fidelity and Theory, 47 STAN. L. REV. 395 (I995) (same).

274 Lessig, supra note 88, at I4I; see also id. at I37-4I (discussing the growth of interstate commerce and economic integration).

275 Id. at $\mathrm{I} 30$. 
Commerce Power would have excluded most, if not all, of the regulatory interventions handled by the new federalism, ${ }^{276}$ then perhaps the Court's novel construction of implied limitations on the power clauses merely "restor[es] a balance envisioned in the framing generation." 277 Or, put another way, "to be faithful to the constitutional structure, the Court must be willing to be unfaithful to the constitutional text." 278

Whatever the virtues or vices of translation in general, ${ }^{279}$ let me suggest two related grounds for hesitation about its application to the new federalism. First, translation here presupposes a discernable state-federal balance to be restored. If, as I have suggested, there is no freestanding federalism apart from the particular implementing provisions, then identifying a benchmark for fidelity may be difficult, if not impossible. ${ }^{280}$ Second, as a conceptual matter, the effort to return to a hypothetical balance begs the question of whether the underlying bargain itself left room for the accommodations of legal or factual developments that the founders did not contemplate. If the possibility of legislative compromise suggests that interpreters should pay close attention to the level of generality at which lawmakers write their laws, then an open-ended law may suggest a choice, whether implicit or explicit, to leave some questions for the future or to allow for the assimilation of change. In the statutory setting, the Court has been reluctant to constrain a broad law to a narrow view of its purpose, perhaps in deference to the choice the broad language represents. The Court has thus said that "the reach of a statute often exceeds the precise evil to be eliminated" and that "it is not, and cannot be, our practice to restrict the unqualified language of a statute to the particular evil that

276 See generally United States v. Lopez, 5 I4 U.S. 549, 585-93 (I995) (Thomas, J., concurring) (discussing original meaning); Epstein, supra note 2 I9, at I387-99 (same).

277 Lessig, supra note 88, at I30.

278 Id. at I93. Starting from Burkean premises, Professor Young similarly argues that the Court is justified in making "compensating adjustments" that may not be fully warranted by the constitutional text, but that restore the doctrine to a traditional state-federal balance. See Young, supra note 90 , at $\mathrm{I} 783-99$.

279 The approach, although widely embraced, has attracted some criticism. See, e.g., Clark, supra note I 22 (arguing that fidelity may preserve the state-federal balance but, in so doing, violates the contemplated balance of power between the judiciary and the political branches); Michael J. Klarman, Antifidelity, 70 S. CAL. L. REV. 38I, 395 (1997) ("The obvious problem with the enterprise is one of indeterminacy - translating old concepts into modern contexts inevitably implicates the very sort of unconstrained judicial subjectivity that translation's proponents seek to avoid.").

280 In his dissent in Alden v. Maine, ${ }_{52} 7$ U.S. 706 (I999), Justice Souter observed the change in background understandings of federal power, but drew the conclusion not that the Court should enforce a vision of new federalism but rather that conceptions of sovereign immunity should be updated to correspond to the modern understanding of the Commerce Clause. See id. at 807 (Souter, J., dissenting) ("If the Framers would be surprised to see States subjected to suit in their own courts under the commerce power, they would be astonished by the reach of Congress under the Commerce Clause generally."). 
Congress was trying to remedy - even assuming that it is possible to identify that evil from something other than the text of the statute itself."281 Professor Lessig must explain why the same principle should not apply to the Commerce Clause if he is otherwise correct about the open-ended quality of its text.

In any case, the Court's stated justifications for the modern federalism do not rest on those theories of translation. If the Court's high level purposive abstraction is merely a second-best way to recapture or at least compensate for long lost understandings of a specific text like the Commerce Clause, the Court should say so. ${ }^{282}$ In so doing, it should identify the concrete understandings of the Commerce Clause that it is trying to restore through implementing doctrines that have nothing to do with an understanding of the terms "Commerce among the States." Otherwise, its approach just appears to enforce a freestanding federalism that does not exist.

\section{CONCLUSION}

Professor Charles Black once wrote that interpreters should derive constitutional meaning, in part, through "the method of inference from the structures and relationships created by the constitution in all parts or in some principal part." ${ }^{283}$ That admonition can describe a range of approaches. At one end of the spectrum, it can stand for nothing more than the proposition that when a structural provision is semantically indeterminate, its meaning can sometimes be illuminated by considering its fit with, and functional relationship to, other provisions of the text. $^{284}$ Modern textualists readily embrace such an approach, "not because that precise accommodative meaning is what the lawmakers

\footnotetext{
281 Brogan v. United States, 522 U.S. 398, 403 (I998) (Scalia, J.). As Professor Max Radin once wrote: "[T]he legislature can not both have its cake and eat it. It can not indulge itself in using large, round, sonorous words and then complain that courts do not treat them as precise, definite, and unreverberant." Radin, supra note 6I, at 884.

282 See, e.g., David L. Shapiro, In Defense of Judicial Candor, roo HARV. L. REV. 731, 750 (I987) ("[T]he fidelity of judges to law can be fairly measured only if they believe what they say in their opinions and orders, and thus a good case can be made that the obligation to candor is absolute.”; David A. Strauss, Originalism, Precedent, and Candor, 22 Const. Comment. 299, 30809 (2005) (arguing for interpretive methodologies that encourage candor).

283 Charles L. Black, JR., Structure and Relationship in CONSTitutional LaW 7 (I969).

284 See Bradford R. Clark, Federal Lawmaking and the Role of Structure in Constitutional Interpretation, 96 CAL. L. REV. 699, 720 (2008) ("[I]n analyzing a decision that implicates the constitutional structure, one must pay close attention to the constitutional text and its surrounding context. This context includes the structure created by the text...."); Henry P. Monaghan, The Supreme Court, 1974 Term-Foreword: Constitutional Common Law, 89 HARV. L. REV. I, I3 n.72 (I975) ("[T]he traditional method of 'interpreting' textual provisions is hardly inconsistent with taking into account structural considerations. The former are often simply the textual embodiment of the latter.").
} 
must have had in mind ..., but because it is [the judiciary's] role to make sense rather than nonsense out of the corpus juris,"285 at least when the semantic indeterminacy of a particular clause so permits.

Professor Black's approach, however, can also be understood to mean that the overall structure takes on a life of its own, providing the source for values that are attached to no particular clause of the document but are nonetheless enforceable as law. ${ }^{286}$ That form of the technique characterizes the new federalism cases. As discussed, the cases tease out a general purpose (federalism) from multiple discrete provisions that implement that background purpose in relatively precise ways. This approach, which I have characterized as multiclause holism, inevitably shifts the level of generality at which those provisions express their purpose. By embracing a freestanding federalism, the Court has necessarily moved from what Max Radin usefully called the "immediate purpose" (specific meaning) of the enacted text to its "ultimate purpose" (background justification), which can be stated at many different levels of generality. 287

Measured against the process assumptions that the Court has developed in its statutory cases, such freestanding federalism is problematic. If one takes seriously the Court's premise that it must root its holding in some understanding of the document that is traceable to the constitutionmaking process, then the process rationale for the Court's statutory technique - the need to give effect to a lawmaker's choice of means as well as ends - applies no less to decisions about constitutional meaning. The precise contours of any federal system rest on the

285 W. Va. Univ. Hosps. v. Casey, 499 U.S. 83, I00-OI (I99I) (Scalia, J.).

286 Some of Professor Black's affirmative examples illustrate the danger of describing the structural policy at so high a level of generality that it becomes divorced from the specific provisions that create it. For example, referring to the facts of Carrington v. Rash, 380 U.S. 89 (I969), Professor Black would have used structure and relationship to invalidate state constitutional limits on the right of a member of the Armed Services to vote in local elections. For him, the "logic of national structure, as distinguished from the topic of textual exegesis," would have justified concluding that "no state may annex any disadvantage simply and solely to the performance of a federal duty." BLACK, supra note 283 , at II. Just as it is difficult to infer particular restrictions on federal power from the broad proposition that we have a dual sovereignty, it is equally difficult to infer particular restrictions on state power from the broad proposition that we are a nation.

Even admirers of Professor Black's approach acknowledge its potential open-endedness. See, e.g., Michael C. Dorf, Interpretive Holism and the Structural Method, or How Charles Black Might Have Thought About Campaign Finance Reform and Congressional Timidity, 92 GEO. L.J. 833,833 (2004) (noting that "the structural method that Black advocated places a great deal of power in the hands of those who would employ it"); John Harrison, Review of Structure and Relationship in Constitutional Law, 89 VA. L. REV. I779, I 786 (2003) (book review) (noting some indeterminacies in the way Professor Black's structural approach might move from broad structural principle to necessary doctrinal detail).

287 As noted, Max Radin wrote that the purposes of all laws can be expressed at many levels of generality, and that the "ultimate purposes of all statutes, because of all law, are justice and security." See Radin, supra note $6 \mathrm{I}$, at 876 . 
allocation of political power rather than matters of principle. And the historical record, as well as the constitutional text, reveals that the founders bargained hard about the appropriate means of allocating state and federal power. Treating the Constitution as if it adopts freestanding federalism, apart from the many specific provisions that implement it, disregards that reality and devalues the compromises that gave rise to "Our Federalism."

The Court once wrote that "[t]he principle of separation of powers was not simply an abstract generalization in the minds of the Framers: it was woven into the document that they drafted in Philadelphia in the summer of I $787 . " 288$ That insight applies no less to federalism.

288 Buckley v. Valeo, 424 U.S. I, I24 (1976) (per curiam); see also Boumediene v. Bush, I28 S. Ct. 2229, 2297 (2008) (Scalia, J., dissenting) ("Only by considering [structural provisions] one-byone does the full shape of the Constitution's separation-of-powers principles emerge. It is nonsensical to interpret those provisions themselves in light of some general 'separation-of-powers principles' dreamed up by the Court."). Consistent with that view, many of its cases have focused on the meaning of the particular clauses of the Constitution that create the structures at issue in a given case - such as the Bicameralism and Presentment Clause of Article I, the Appointments Clause of Article II, the Take Care Clause of Article II, or the Vesting Clause of Article III. See, e.g., Plaut v. Spendthrift Farm, Inc., 5 I4 U.S. 2 I I, 2 I 8 (I995) (holding that "the judicial Power," U.S. CONST. art. III, § I, includes the power to enter final judgments unrevisable by the legislature); Morrison v. Olson, 487 U.S. 654, 689-90 (i 988) (observing that the Court's removal case law has sought "to ensure that Congress does not interfere with the President's exercise of the 'executive power' and his constitutionally appointed duty to 'take care that the laws be faithfully executed' under Article II"); INS v. Chadha, 462 U.S. 919, 946-5 I (I983) (holding that the bicameralism and presentment requirements, see U.S. CONST. art. I, § 7, constitute the exclusive means for Congress to enact legislation); Buckley, 424 U.S. at I $24-37$ (concluding that Congress lacks authority to provide for the appointment of "Officers of the United States" outside the carefully reticulated procedures prescribed by the Appointments Clause, U.S. CONST. art. II, § 2, cl. 2).

Of course, the Court sometimes honors its admonition in the breach, invoking the separation of powers as a freestanding abstraction divorced from the interpretation of any particular clause. See, e.g., Bowsher v. Synar, 478 U.S. 7I4, 723 (I986) ("A direct congressional role in the removal of officers charged with the execution of the laws beyond [impeachment] is inconsistent with separation of powers."); Nixon v. Adm'r of Gen. Servs., 433 U.S. 425, 44I (I977) (evaluating whether the disposition of President Nixon's records violated "the principle of separation of powers"). When the Court does so, its reasoning is subject to the same concerns that characterize its approach to freestanding federalism. 